\title{
A MIRA DA CONDOR
}

\author{
"Em tempos de paz, os filhos enterram os pais. \\ Em tempos de guerra, os pais enterram os filhos. \\ Em tempos de Condor, nem isso". \\ (Luiz Claudio Cunha, Brasília, 25 de fev. 2013).
}

\section{Resumo}

Este artigo visa descrever a estrutura, os métodos e a atuação da Operação Condor durante a vigência dos regimes militares no Cone Sul. A metodologia adotada foi à pesquisa bibliográfica e a pesquisa documental, baseada no cruzamento de fontes e evidências de origens diversas: documentos oficiais e militares dos "Arquivos do Terror" e do "Fundo Clamor". O argumento central dessa pesquisa consiste na afirmação de que a atuação dos agentes de segurança do Brasil, Paraguai, Argentina, Uruguai e Chile, através da participação na Operação Condor, foi responsável pela violação dos direitos humanos de milhares de cidadãos desses países, sobretudo de mulheres grávidas detidas e crianças sequestradas, aumentando o número de desaparecidos políticos durante o período ditatorial militar.

Palavras-chaves: Operação Condor. Ditadura Militar. Direitos Humanos. Cone Sul. Brasil.

\section{INTRODUÇÃO}

Entre os anos de 1954 a 1990, nos países do Cone Sul², sucessivas ditaduras civis militares foram instaladas após a derrubada de governos civis, na maioria eleitos democraticamente ${ }^{3}$. A Operação Condor foi uma ação conjunta das forças repressoras do Brasil, Argentina, Chile, Paraguai e Uruguai, criada em 1975. A função principal dessa operação era neutralizar e reprimir os grupos que se opunham aos regimes militares instalados na América do Sul. O nome da operação faz referência a uma ave andina, símbolo de astúcia na caça às suas presas. A associação do nome da operação com os hábitos da Condor fornece uma noção do que representava essa

\footnotetext{
${ }^{1}$ Pós-doutora em História pela Universidade Federal de Minas Gerais na área Memória e História, com ênfase no período das ditaduras militares dos países do Cone Sul na América Latina e do Brasil. Professora Adjunta do Curso de Direito do Centro Universitário UNA. Pesquisadora do Projeto República: núcleo de pesquisa, documentação e memória, da Faculdade de Filosofia e Ciências Humanas da Universidade Federal de Minas Gerais. E-mail: annaflav@prof.una.br

${ }^{2}$ Entende-se por Cone Sul a região geográfica que engloba a parte sul do continente sul-Americano. A região é composta pelo Uruguai, Argentina e Chile e tem esse nome devido à sua aparência de um triângulo. Em função das suas localizações geográficas, o Paraguai e a região Sul do Brasil são consideradas parte do Cone Sul.
} 
organização e de como ela agia no combate à subversão, aos comunistas e aos opositores dos regimes militares (PADRÓS, 2009; MARIANO, 2003).

Segundo o jornalista Luiz Claudio Cunha (2008), o Brasil passou a integrar essa operação somente em 1976. Em 1975, apesar do general João Baptista Figueiredo, na época chefe do Serviço Nacional de Informação (SNI) no Brasil, ser amigo do Coronel Manuel Contreras, diretor da Dirección de Inteligencia Nacional $(D I N A)^{4}$ no Chile, o general brasileiro optou por enviar dois representantes para se inteirarem do assunto da reunião realizada no Chile, sem assinar nenhum documento. Participaram da reunião o major Thaumaturgo Sotero Vaz e o coronel Flávio de Marco. Ambos com experiências em atos repressivos na Guerrilha do Araguaia ${ }^{5}$.

Essa conexão permitia que os comandantes militares das Forças Armadas, os serviços de inteligência e as polícias políticas dos países envolvidos atuassem em todo o continente sul-americano sem qualquer tipo de obstáculo legal ou jurídico. Para os comandantes das forças armadas a luta contra o terrorismo não tinha fronteiras.

A metodologia adotada para a realização desse estudo foi a pesquisa documental, baseada na observação sistemática de fontes primárias retrospectivas selecionadas nos documentos do Fundo Clamor ${ }^{6}$ e nos "Arquivos do Terror ${ }^{7 ”}$. Os critérios de seleção foram baseados nos registros de detenção e tortura de mulheres; sequestro,

\footnotetext{
${ }^{3}$ Os golpes civis militares nos países do Cone Sul ocorreram nos seguintes períodos: Paraguai (1954-1989), Brasil (1964-1985), Argentina (1966-1973 e 1976-1983), Uruguai (1973-1985), Chile (1973-1990).

${ }^{4}$ A Dirección de Inteligencia Nacional (DINA), foi criada em 1974, com o apoio do general e ex-presidente chileno Augusto Pinochet. Era um organismo centralizado e subordinado diretamente ao Executivo. Inicialmente a DINA foi responsável pela coleta e reunião de informações originárias dos diferentes campos de ação, auxiliando na produção da inteligência necessária para formulação de políticas que visavam garantir a segurança do país. Desde o momento de sua criação até a sua extinção em 1977, a DINA foi dirigida pelo coronel Manuel Contreras. A maioria dos integrantes da DINA provinha das Forças Armadas e de Segurança enquanto que os cargos de direção se concentravam nas mãos de militares do Exército (ANTUNES, 2008, p. 227).

${ }^{5}$ Guerrilha desencadeada entre o final dos anos 1960 e a metade da década de 1970, na região amazônica, com o propósito de promover uma revolução socialista (BARRETO, 2015).

${ }^{6}$ O Fundo Clamor encontra-se distribuído em 106 caixas arquivo, 28 pastas para periódicos e 1 pasta para arquiteto. Reúne documentos textuais, orais e iconográficos. Os documentos foram adquiridos através de doação do Centro Ecumênico de Serviços à Evangelização e Educação Popular (CESEP), em 1993. Vale ressaltar que a documentação disponível para consulta no Fundo Clamor não corresponde a totalidade dos documentos registrados pelo Comitê de Defesa dos Direitos Humanos para os Países do Cone Sul (Clamor), mas somente à documentação doada pelo Centro Ecumênico ao Centro de Documentação e Informação Cientifica CEDIC, da Pontifícia Universidade Católica de São Paulo. Dessa documentação, selecionamos atas de reuniões, folhetos, boletins, cartilhas, jornais e publicações do Comitê, reportagens de jornais da grande imprensa e jornais alternativos arquivadas no Fundo, correspondências e denúncias recebidas, resoluções de reuniões, relatórios, mapeamento das principais atividades desenvolvidas pelo Comitê e dos refugiados atendidos pelo Comitê. Através desses registros, foram selecionados documentos cujas informações remetiam ao desaparecimento de crianças e/ou à prisão e sequestro de militantes grávidas, procurando descrever a situação da apreensão e encarceramento, contexto histórico, forças repressoras envolvidas na operação de prisão, sequestro e/ou tortura das militantes e das crianças envolvidas.

${ }^{7}$ A base de dados dos Arquivos do Terror contém cerca de 60.000 registros dos documentos recolhidos ao longo dos trinta e cinco anos da ditadura do general Alfredo Stroessner que estão localizados no Centro de Documentação e Arquivo para a Defesa dos Direitos Humanos (CDyA) do Supremo Tribunal de Justiça do Paraguai. Esta base de Base de dados foi desenvolvida através do Projeto Memória Histórica, Democracia e Direitos Humanos (MHDDH), acordo firmado entre o Supremo Tribunal de Justiça, da Universidade Católica de Assunção e da ONG The National Security Archive. Cada registro inclui o código para imagens de microfilme, data do documento, tipo de documento, linha e nome; e se for o caso, a origem, as organizações e localização geográfica. São fichas policiais, listas de entradas e saídas de presos, notas do chefe de investigações, informes confidenciais, controle
} vol.10, nº. 03, Rio de Janeiro, 2017.pp. 1398-1431 
prisão e desaparecimento de crianças, durante o período de vigência dos governos militares no Cone Sul. Especial atenção foi dada às imagens do rolo de microfilme 143, onde constam registro das atividades da Operação Condor nos países do Cone Sul. Foram encontrados e analisados documentos referentes a cooperação conjunta do Brasil e países vizinhos na troca de informações referentes aos prisioneiros detidos no Cone Sul, ao translado de prisioneiros detidos, às informações conseguidas nos interrogatórios. Além disso, foram analisados atas das reuniões realizadas pelos membros dos países integrantes da Operação Condor, fichas e prontuários de prisioneiros detidos e trocados entre os países.

A originalidade da pesquisa encontra-se na produção de um trabalho acadêmico no campo da História e do Direito, que busque analisar as informações contidas no Fundo Clamor ${ }^{8}$ e nos "Arquivos do Terror" como contribuição para o resgate da memória das ditaduras civis militares, sobretudo no que se refere às ações da Operação Condor e o protagonismo brasileiro na troca de informações sobre prisioneiros políticos e técnicas de interrogatório, com estreita cooperação dos países do Cone Sul.

Acreditamos que a reconstituição da memória deste período (1954-1990), através da análise dos documentos do "Fundo Clamor" e dos "Arquivos do Terror", poderá contribuir para a recuperação de uma história omitida pelos discursos autoritários dos órgãos da repressão política e militar. Trata-se de uma pesquisa sobre casos de violações dos direitos humanos de três gerações (avós, pais e filhos) que, devido às convicções políticas contrárias à ideologia oficial, foram usurpados de seus direitos humanos e de cidadãos.

Iniciamos nosso relato com uma descrição do contexto histórico das ditaduras civis militares no Cone Sul e suas relações com a Operação Condor, em seguida apresentamos a estrutura de funcionamento da Condor, suas fases e métodos de ação. Finalmente apresentamos algumas formas de resistências desenvolvidas por organizações das sociedades civis às ações da Operação Condor.

\section{AS DITADURAS CIVIS MILITARES DO CONE SUL E A CONDOR}

A crescente onda de insatisfação e enfrentamentos políticos e sociais presentes nos países do Cone Sul fazia parte do contexto da Guerra Fria, em um mundo marcado pela bipolaridade ideológica entre os blocos

\footnotetext{
de partidos políticos, publicações periódicas, listas de suspeitos, informações sobre agremiações e grupos considerados subversivos, controle de sindicatos e objetos como livros e cédulas de identidade. Os documentos pertenciam a Polícia da Capital, especialmente ao Departamento de Investigações da Direção Nacional de Assuntos Técnicos.

${ }^{8}$ Apesar dos últimos registros do Fundo Clamor datar de 1990, ressaltamos que se trata de documentos pouco explorados e analisados dentro do campo da História e do Direito. Existem somente dois estudos acadêmicos que utilizaram dessa documentação para a realização de pesquisa. Um deles é o livro "Clamor: a vitória de uma conspiração brasileira" de Samarone Lima. O livro descreve a história e trajetória do grupo Clamor em defesa dos direitos humanos dos refugiados políticos dos países do Cone Sul. O outro, não menos importante, de Ana Célia Navarro Andrade, "Inventário do Fundo Clamor: organização e descrição do Fundo Comitê de Defesa dos Direitos Humanos para os países do Cone Sul”, faz um levantamento historiográfico do Fundo Clamor e discute os procedimentos arquivísticos desenvolvidos para o arranjo e a descrição do Fundo Clamor, pertencente ao acervo do Centro de Documentação e Informação Cientifica CEDIC, da PUC/SP.
} 
liderados pelos Estados Unidos da América (EUA) que patrocinavam os regimes capitalistas e pela União das Repúblicas Socialistas Soviéticas (URSS) que defendiam o socialismo. Neste contexto é importante destacar o impacto causado pela Revolução Cubana, em 1959, com a implantação de um regime socialista em um país próximo geograficamente dos EUA, o que levou a "superpotência considerar a política interna de cada país da região como extensão de sua própria política externa" (PADRÓS, 2005, p. 47).

A Guerra Fria entre URSS e EUA que dominou o cenário internacional na segunda metade do século XX fez com que gerações inteiras se criassem à sombra de possíveis batalhas nucleares globais com potencial para devastar a humanidade. Contudo, o medo da destruição mútua inevitável impediria um lado ou outro de dar o sempre pronto sinal para o planejado suicídio da civilização. Assim, a peculiaridade da Guerra Fria era a de que, em termos objetivos, não existia perigo iminente de guerra mundial.

Para a América Latina, o grande impacto da Guerra Fria não foi as armas nucleares e nem a corrida armamentista, mas sim a "guerra de contra insurgência", baseada na Doutrina de Segurança Nacional, que tinha como objetivo eliminar possíveis revoluções sociais nas áreas de influência ideológica dos EUA. De acordo com o Secretário do governo Kennedy, Robert Mc Namara, três tipos de guerras eram consideradas naquele contexto de Guerra Fria: a guerra atômica, a guerra convencional, a guerra não convencional. $\mathrm{O}$ último tipo de guerra foi interpretado como uma estratégia do Movimento Comunista Internacional na conquista de adeptos para o socialismo. Nesse sentido, o novo desafio para o EUA era conter a guerra não convencional ou guerra revolucionária através da instalação da Doutrina de Segurança Nacional e dos regimes ditatoriais na América do Sul (REIS, 2012, p. 34).

A justificativa ideológica para a adoção e implantação dessas políticas nos países da América Sul era a promoção da liberdade, a defesa da democracia e o combate à subversão. Essa ideologia era baseada na Doutrina de Segurança Nacional que tinha origem na Escola Superior de Guerra dos Estados Unidos da América e foi amplamente adotada pelas forças armadas dos países latino-americanos para combater os inimigos do Estado. A base dessa doutrina era a concepção positivista que buscava interpretar o corpo político e social a partir de um modelo orgânico, cujo funcionamento perfeito dependia do funcionamento adequado de todas as partes que compunha o restante do corpo. Todos aqueles que se opunham a lógica positivista deveriam ser automaticamente eliminados a fim de garantir o bom funcionamento do corpo social em constante desenvolvimento. Em nome da ordem e da segurança nacional, os opositores do novo governo eram detidos, torturados, mortos e desaparecidos (FERNANDES, 2009; PADRÓS, 2007; MARTINS FILHO, 1999).

A instituição de ditaduras nos países do Cone Sul teve início em maio de 1954, no Paraguai, com o golpe de estado do general Alfredo Stroessner, apoiado pela Junta de Governo do Partido Colorado e por grande parte da população, que depôs o presidente Frederico Chávez e nomeou como presidente interino Toman Romero 
Pereira, para posteriormente convocar eleições. No mesmo ano, no dia 11 de julho, o general Alberto Stroessner, candidato único do Partido Colorado, que apoiou o golpe militar, ganhou as eleições presidenciais. Em 15 de agosto de 1954, Stroessner tornou-se Presidente do Paraguai. A partir de então, teve início um regime ditatorial unipessoal, que contou com práticas de torturas aos seus opositores e com a criação de um sistema de delação, levando centenas de paraguaios aos cárceres e ao desparecimento. (ALVAREZ, 2010; MARIANO, 2003; VERA, 2010).

Além do Partido Colorado, o general Stroessner contou com o apoio da oligarquia agropecuária e dos Estados Unidos da América. Segundo Miguel López (2010), pouco após Stroessner assumir a presidência, ele assinou um acordo com os altos oficiais americanos e brasileiros, onde se comprometia a barrar qualquer ameaça comunista.

Para impedir o avanço do comunismo no Paraguai, a ditadura do general Stroessner impôs a filiação partidária ao Partido Colorado como condição primordial para ter acesso aos cargos públicos e ingressar nas Universidades. Além disso, a exigência de filiação ao Partido Colorado aconteceu por parte das empresas privadas na contratação de pessoal, cujos proprietários eram aliados do governo. Assim, o Partido Colorado se tornou a base social da ditadura paraguaia e os sindicatos e movimentos estudantis eram formados basicamente por colorados. Esta estratégia deixou a oposição ao regime militar cada vez mais debilitada (VERA, 2010). Uma das vítimas da ditadura paraguaia durante o governo do general Stroessner foi o advogado Martín Almada que, desejoso de conhecer detalhes das acusações que o colocara preso entre 1974 a 1977 e da morte de sua esposa, solicitou um habeas data ${ }^{9}$ às autoridades judiciais paraguaias. Em 1992, atendendo ao pedido de habeas data do advogado, as autoridades encontraram em Lambaré, cidade que fica a vinte quilômetros de Assunção, um acervo composto de cerca de 60.000 registros de documentos contendo informações sobre a ditadura do general Stroessner. Entre os documentos encontrados ressaltam-se os documentos relativos ao funcionamento da Operação Condor com a ação conjunta dos países Brasil, Paraguai, Chile, Uruguai, Argentina (PAZ, 2008, 1994).

Segundo López (2010), antes de assumir a presidência Stroessner se reuniu secretamente com membros do Comando Sul dos Estados Unidos. Nesta reunião foi assinado um pacto com altos oficiais americanos e brasileiros, como parte do plano dos aliados anticomunistas durante a Guerra Fria e a Doutrina de Segurança Nacional, implantada na década de 1960, por meio da ditadura militar brasileira.

Com a desaceleração econômica nos anos de 1980, a ditadura militar paraguaia começou a perder força e apoio. Nos dias 2 e 3 de fevereiro de 1989 um novo golpe, planejado por alguns setores do Partido Colorado,

\footnotetext{
9 "Ação para garantir o acesso de uma pessoa a informações sobre ela que façam parte de arquivos ou bancos de dados de entidades governamentais ou públicas. Também pode pedir a correção de dados incorretos” (BRASIL. Supremo Tribunal Federal. Glossário Jurídico. Habeas Data. Disponível em: http://www.stf.jus.br/portal/glossario/verVerbete.asp?letra=H\&id=156. Acesso em 02 fev. 2016.)
} 
destituiu Stroessner da presidência. Durante a Ditadura Militar do general Alfredo Stroessner, milhares de paraguaios foram detidos, torturados, exilados e muitos desaparecidos. A ditadura paraguaia (1954-1989) gerou traumas e ressentimentos ainda presentes na população. Como todas as ditaduras latino-americanas, ela violou os direitos humanos, cerceou liberdades e promoveu mortes e desaparecimentos de cidadãos em nome da Segurança Nacional (LOPEZ, 2010).

Na sequência de instituição de regimes ditatoriais na América do Sul, o Brasil foi o próximo país a sofrer um golpe civil militar que derrubou um presidente eleito democraticamente. Em 31 de março de 1964 o regime militar implantando no Brasil depôs o governo constitucional do presidente João Goulart e emitiu diversos Atos Institucionais que aumentaram o poder da Presidência da República e limitaram os direitos individuais dos cidadãos. A imprensa, os sindicatos e as organizações estudantis ficaram sobre forte censura do Estado (ALVES, 1989; BARRETO, 2011).

O período do Regime Militar Brasileiro foi marcado pela influência da Doutrina de Segurança Nacional e explicitou um conjunto de políticas que, sob a máxima "desenvolvimento com segurança”, articulou medidas de efetivo controle social com estratégias econômicas de maior inserção do Brasil na ordem capitalista internacional. A realização da lógica "estabilidade e crescimento econômico" só foi possível devido à eliminação pela via da coerção do conflito no interior da sociedade. Gradativamente, o ciclo de repressão estendeu-se aos indivíduos considerados suspeitos no interior da esfera do Estado e, com as manifestações estudantis de 1968, à classe média. Em todo o Brasil, a repressão aos grupos "subversivos" se fez presente. (ALVES, 1989; D'ARAÚJO, 1994; DREIFUSS, 1981).

As primeiras medidas do regime militar, durante o governo do general Castelo Branco, apresentaram uma clara intenção de eliminar a oposição ao regime militar. O governo Castelo fez uso intenso de manobras policiais-militares de detenção em massa com bloqueio de ruas, busca de casa em casa e checagem individual; de prisões de massa; da prática da tortura como forma de interrogatório em diversas guarnições militares. Entre os anos de 1964 a 1967 o governo interveio nos sindicatos e nas entidades estudantis, proibiu a realização de greves, instaurou a censura nos meios de comunicação, criou o Sistema Nacional de Informações, cassou mandatos e suspendeu por dez anos os direitos políticos dos parlamentares oposicionistas (ALVES, 1989).

O ano de 1968 foi um marco de ambivalência no regime militar. Neste ano verificou-se tanto a efervescência dos movimentos oposicionistas como a intensificação da repressão do Estado (GORENDER, 1987; PERRONE, 1988; VENTURA, 1988; REIS; MORAIS, 1988). Em 1968, o governo do general Costa e Silva, em resposta a eclosão de um amplo movimento social de protesto e de oposição à ditadura, decretou o Ato Institucional no 5, considerado, por muitos autores, como um "golpe dentro do golpe" (ALVES, 1989, p. 121). O 
Ato Institucional No 5 proibiu as greves, ampliou o poder do executivo para efetuação de prisões sem mandatos judiciais e promoveu novas cassações.

O fator conjuntural que mais contribuiu para a edição do AI-5 foi a intensificação da contestação ao regime pelos sindicatos e movimento estudantil como também por alguns segmentos do MDB.

Os três fatores utilizados como pretextos pelas Forças Armadas para desencadearem nova escalada repressiva com o Ato Institucional n ${ }^{\circ}$, foram: as denúncias sustentadas dentro do próprio partido de oposição criado pelo regime, o crescimento das manifestações de rua e o surgimento de grupos de oposição armada, que justificavam sua decisão com o argumento de que os canais institucionais seriam incapazes de fazer frente ao poder ditatorial (ARNS, 1985, p. 62).

Entre os anos de 1969 a 1973, observou-se a ocorrência das guerrilhas rural e urbana que acirraram ainda mais a ação repressiva das forças armadas. A finalidade dessas guerrilhas era converter-se em um exército popular revolucionário capaz de empreender a derrubada do regime militar e a instalação de uma sociedade socialista e democrática (BARRETO, 2015, p. 86-111). Inúmeros militantes das organizações de esquerda foram presos e muitas vezes, torturados.

Para Ana Vasquez e Ana Araújo (1988), o objetivo da tortura não era apenas a obtenção de informações, mas, sobretudo, a anulação daquelas pessoas, de forma permanente e definitiva. O depoimento do ex-sargento dos órgãos de informação do Exército, Marival Dias Chaves do Canto, é elucidativo da questão. Segundo ele, os corpos eram mutilados, esquartejados e ocultados. Alguns morriam na tortura.

Eles matavam e esquartejavam. Eles faziam isto para dificultar a descoberta e a identificação do morto [...] amputavam as falangetas dos dedos para evitar que os mortos fossem reconhecidos através das impressões digitais. Boa parte dos mortos não está sob a terra, mas sob a água (FILHO, 1992, p. 24).

À medida que o regime autoritário foi se consolidando no Brasil, os canais de manifestação da sociedade civil foram sendo cortados. O governo militar buscava o progresso da Nação e posterior garantia da "democracia", através exclusão política dos que não se integravam ao projeto governamental,da manutenção da ordem e da segurança nacional (DREIFUS, 1971; ALVES, 1988).

O lema positivista "Ordem e Progresso" era adotado ao pé da letra pelo regime. Em prol desse objetivo, combatiam-se todas as manifestações populares vistas como subversivas. Além disso, a ameaça do comunismo era entendida pelos governantes como uma ameaça ao país. Com o objetivo de combater os inimigos da nação, o autoritarismo se aprofundava. O principal alvo da repressão eram as organizações de esquerda e os movimentos estudantis e operários. O golpe civil e militar, que contou com o apoio de expressivos segmentos da classe média brasileira, contrariou os interesses dessa classe à medida que se consolidava o regime autoritário. "A classe média se sentiu traída. E sua amargura estimulou a luta e o protesto dos estudantes" (REIS; MORAIS, 1988, p. 12). Nesse sentido, o movimento estudantil ganhou força, simultaneamente ao recrudescimento da repressão. Vale ressaltar que muitos dos participantes do movimento estudantil pertenciam à classe média. 
A classe operária foi uma das mais atingida pela repressão militar no imediato pós 1964. Seus líderes foram presos e inúmeros sindicatos sofreram intervenção. O golpe civil militar pretendia "colocar os trabalhadores manuais em seus devidos lugares, liquidar pela força o que havia sido conquistado em longas e incertas negociações" (REIS; MORAIS, 1988, p. 25). Após 1964, houve somente uma pequena reaparição do movimento operário quando das greves de Contagem e Osasco em 1968. Em seguida a repressão sobre os sindicatos se aprofundou e os mesmos só voltaram a se manifestar em 1978, já às vésperas da anistia política (ALVES, 1989).

Nesta conjuntura, as "leis" serviam como o melhor instrumento para a repressão e opressão. Tal interpretação baseia-se na abusiva promulgação de Atos Institucionais e Atos Complementares à Constituição (SKIDMORE, 1988; ALVES, 1989). Durante o regime militar, centenas de prisões e mortes de muitos militantes destes movimentos e organizações espalharam um clima de terror e medo na sociedade brasileira (ALVES, 1989).

De abuso cometido pelos interrogadores sobre o preso, a tortura no Brasil passou, com o Regime Militar, à condição de "método científico", incluído em currículos de formação de militares. $\mathrm{O}$ ensino deste método de arrancar confissões e informações não era meramente teórico. Era prático, com pessoas realmente torturadas, servindo de cobaias neste macabro aprendizado (ARNS, 1985, p. 24).

Segundo Padrós (2009, p. 17), o Brasil se tornou laboratório de práticas repressivas e foco disseminador das mesmas (torturas, esquadrões da morte, sequestro, desaparecimento de pessoas). Nos depoimentos que se seguem podemos constatar que a prática da tortura em presos políticos se efetivava tanto como forma de obter informações, quanto como instrumento de demonstrações práticas do funcionamento do sistema de tortura. O estudante Ângelo Pezzuti da Silva, 23 anos, preso em Belo Horizonte e torturado no Rio de Janeiro, narrou ao Conselho de Justiça Militar de Juiz de Fora, no ano de 1970:

(...), que, na PE (Polícia do Exército), da GB, verificaram o interrogado e seus companheiros que as torturas são uma instituição, uma vez que, o interrogado foi o instrumento de demonstrações práticas desse sistema, em uma aula de que participaram mais de 100 (cem) sargentos e cujo professor era um Oficial da PE, chamado Tnt. Ayton que, nessa sala, ao tempo que projetavam "slides" sobre tortura, mostrava-se na prática para a qual serviram o interrogado, Maurício Paiva, Afonso Celso, Murilo Pinto, P. Paulo Bretas, e, outros presos que estavam na PE-GB, de cobaias (apud ARNS, 1985, p. 31).

O estudante Maurício de Paiva, 25 anos, confirma a denúncia de Ângelo Pezzuti:

(...) que o método de torturas foi institucionalizado em nosso País e, que a prova deste fato não está na aplicação das torturas pura e simplesmente, mas, no fato de se ministrarem aulas a este respeito, sendo que, em uma delas o Interrogado e alguns de seus companheiros, serviram de cobaias, aula esta que se realizou na PE da GB, foi ministrada para cem (100) militares das Forças Armadas, sendo seu instrutor um ten. Hayton, daquela U.M.; que, à concomitância da projeção dos "slides" sobre torturas elas eram demonstradas na prática, nos acusados, com o interrogado e seus companheiros, para toda a platéia (apud ARNS, 1985, p.31).

A repressão militar consistia na institucionalização da tortura e das técnicas de interrogatório, bem como no desenvolvimento de ações e propagandas que tornavam visível a existência do aparato repressivo no país. Neste 
sentido, além da repressão física, os grupos de oposição ao regime militar conviviam com uma constante intimidação ideológica e psicológica, promovida pela campanha de repressão (SKIDMORE, 1987; ALVES, 1989).

Entre o número de desaparecidos políticos durante o regime militar, o período que coincide com o período do "Milagre Econômico Brasileiro" (1969 a 1973) soma cerca de 125 mortos (ARNS, 1985; ARAÚJO, 1995). A maioria dos desaparecimentos ocorreu no período de 1969 a 1975.

Pela distribuição dos processos militares, durante o período compreendido entre 1964 e 1974, podemos distinguir duas fases da repressão: a primeira compreendida entre os anos de 1964 a 1968, que coincide com o período dos governos Castelo Branco e Costa e Silva; e a segunda, entre os anos de 1969 a 1974, que coincide com o mandato do general Garrastazu Médici. Vale ressaltar que, dos 7.367 cidadãos denunciados entre os anos de 1964 a 1974, cerca de 84\% não constam em qualquer comunicação ao juiz das prisões que foram efetuadas (ARNS, 1985).

Sobre essas práticas, no dia 25 de março de 2014, o coronel reformado do Exército brasileiro, Paulo Malhães, admitiu que torturou, matou e ocultou cadáveres de militantes políticos durante a ditadura militar brasileira na chamada "Casa da Morte", em Petrópolis, em depoimento concedido à Comissão Nacional da Verdade. Em seu relato, Malhães não demonstra arrependimento ou remorso com relação à morte, tortura ou ocultação de cadáveres realizados. Para o coronel a tortura é necessária para a obtenção de informações e deve ser aplicada aos presos comuns (FRANCO, 2014).

A respeito da ocultação de cadáveres, segundo Malhães, foi um recurso utilizado com a intenção de não se deixar provas das práticas cometidas com os presos políticos. Nas palavras do coronel: "Naquela época não existia DNA. Quando você vai se desfazer de um corpo, quais partes podem determinar quem é a pessoa? Arcada dentária e digitais. Quebrava os dentes. As mãos, cortava, daqui para cima” (FRANCO, 2014). Em seu depoimento, Malhães se referi aos presos políticos como "terroristas" e demonstra não sentir remorso pelo o que fez. "Quando vejo uma pessoa reclamar que um ente querido morreu, pergunto: se tivesse ficado ao lado da esposa e dos filhos isso teria acontecido?" (FRANCO, 2014).

No Brasil, relatos como esses só vieram a público após a instalação da Comissão Nacional da Verdade ${ }^{10}$. Contudo, a apuração desses fatos e de outros semelhantes ainda encontra obstáculos legais e sociais. Segundo Ribeiro Neto e Féres-Carneiro (2012, p.66-67), “com a negação da abertura dos arquivos militares e a impossibilidade de julgamento dos atos de tortura e desaparecimento, impede-se a reparação, produzindo uma memória oca com a impossibilidade de uma memória psíquica na história da família”.

\footnotetext{
${ }^{10}$ No Brasil, a Comissão Nacional da Verdade foi criada através da Lei 12528/2011 e instituída em 16 de maio de 2012. A principal finalidade da Comissão era apurar casos de graves violações de direitos humanos ocorridos no período de 18 de setembro de 1946 a 5 de outubro de 1988. Em dezembro de 2013, através da medida provisória no 632, o mandato da CNV foi prorrogado até dezembro de 2014 (Disponível em: http://www.cnv.gov.br/institucional-acesso-informacao/a-cnv.html. Acesso em 07 de fevereiro de 2016).
} 
A institucionalização da tortura criou na sociedade brasileira uma "cultura do medo", que intimidava as mobilizações de oposição e inibia a participação política. O protesto público era sufocado pelo medo da repressão física. Contudo, com o tempo, passado a dor da tortura e cicatrizadas as feridas, ficou a raiva e a revolta contra o estabelecimento do terror e da dor. Progressivamente, o "medo cultural", advindo da regularidade das torturas, foi vencido pela cólera da opressão diária (ALVES, 1989).

O desgaste da legitimidade do regime, cotidianamente apontada pela ação oposicionista de setores da sociedade civil contribuiu no processo de redemocratização brasileira. Entre eles destacamos: a oposição oficial ao governo e a ação dos movimentos da sociedade civil (mulheres, associações de bairro, grupos étnicos, etc), movimento dos trabalhadores, dos sindicatos, das igrejas (BARRETO, 2011).

O regime militar foi solapado quando a sociedade civil encontrou condições de manifestar. As ruas das cidades foram tomadas pelos mais diversos movimentos por liberdades e direitos: sindicais, estudantis, das mulheres, das igrejas, dos negros. Verificou-se um avanço da emancipação econômica e sexual da mulher simultaneamente à sua crescente presença nos movimentos reivindicatórios e políticos da década (BARRETO, 2011).

Em 1985, através da realização de eleições indiretas para presidência e a vitória do civil Tancredo Neves deuse o fim de vinte e um anos de ditadura militar no Brasil. Vítima de uma enfermidade aguda, Tancredo faleceu antes de assumir a presidência do Brasil. Seu vice, José Sarney, um ex-arenista, assume o comando da Presidência da República Brasileira. Dos países do Cone Sul, depois do Brasil e do Paraguai de Stroessner, foi a vez da Argentina (1966), Uruguai e Chile (1973) e novamente a Argentina (1976).

$\mathrm{Na}$ Argentina, a repressão foi extremamente violenta. A ditadura teve duas etapas. A primeira, de 1966 a 1973, que durou sete anos. A segunda, iniciada em 1976, foi o período que a violência de estado atingiu uma escala sem precedentes na América Latina. Somente em 1983 o país recuperou a democracia. A intensidade da repressão na Argentina revela que o terrorismo de Estado lá aplicado não foi proporcional a ação da subversão. O número de vítimas desse regime reflete a amplitude das punições aplicadas e demonstra que os objetivos dos militares iam além de reprimir (CALVEIRO, 2013; NOVARO, 2007; QUADRAT, 2003).

A repressão argentina concentrou-se em Buenos Aires, responsável por quase metade dos desaparecimentos políticos. Contudo, outras cidades como Córdoba, La Plata e Mendoza tiveram intensa atuação das forças armadas argentinas nas práticas repressivas. Os principais alvos da repressão eram os sindicalistas, membros do partido peronista, intelectuais, estudantes e jornalistas e advogados que defendiam prisioneiros políticos (CATELA, 2008).

Segundo Marcelo Fabián Sain (2000, p.23),

a derrota político-militar das Malvinas marcou o início da ruptura do regime militar inaugurado em 1976. A crise na qual mergulharam as Forças Armadas e, em particular, o governo militar converteu-se rapidamente numa crise do regime.

O processo de transição política na Argentina não ocorreu de forma pactuada como no Brasil, que se desenrolou a partir de uma conciliação entre civis e militares, tendo como produto final a eleição indireta para vol.10, nº. 03, Rio de Janeiro, 2017.pp. 1398-1431 
presidente da República. Diferente do Brasil, a transição argentina tratou-se de uma transição por colapso, determinada pela ruptura do regime militar que teve como golpe final a derrota da Argentina na Guerra das Malvinas (SAIN, 2000, p. 24).

Oficialmente, o governo argentino trabalha com cerca de 9 mil desaparecidos, valor bastante inferior a estimativa dos grupos de direitos humanos que trabalham com um total de 30 mil mortos e desaparecidos políticos no regime militar argentino (MARIANO, 2003, p. 31). Comparativamente, dados do relatório da Secretaria Especial de Direitos Humanos do Brasil apontam como saldos das ditaduras do Cone Sul os seguintes números:

No Brasil foram 50 mil pessoas presas, 20 mil torturados, 356 mortos e desaparecidos, 4 crianças provavelmente sequestradas. No Uruguai foram 166 desaparecidos, 131 mortos, 12 bebês sequestrados, 55 mil detidos. No Paraguai foram de 1 mil a 2 mil mortos e desaparecidos, 1 milhão de exilados. No Chile foram 1.185 desaparecidos, 2.011 mortos (embora estatísticas extraoficiais falem em até 10 mil assassinados), 42.486 presos políticos apenas em 1976. Na Argentina foram 30 mil mortos e desaparecidos (BRASIL, 2009, p. 101).

Nove anos após o início da ditadura militar brasileira, o Uruguai também sofreu um golpe civil-militar em de 27 de junho de 1973 que depôs o presidente civil Juan Maria Bordaberry. Naquele ano, com o apoio das forças armadas, o presidente uruguaio fecha o Senado, a Câmara dos Deputados e anuncia a criação de Conselho de Estado, substituindo o parlamento. O pretexto para a aplicação dessas ações era a necessidade de realizar uma reforma constitucional que enfatizasse os princípios republicanos e democráticos no Uruguai. Em função dessa estratégia, a Convenção Nacional dos Trabalhadores foi colocada na ilegalidade e seus dirigentes foram presos. A ditadura uruguaia se estendeu até 28 de fevereiro de 1985, após um lento processo de abertura política (MARIANO, 2003; PADRÓS, 2005).

Em 1973, no mesmo ano do golpe civil militar do Uruguai, o Chile sofreu um golpe de estado que culminou na execução do presidente, de tendência socialista, Salvador Allende, democraticamente eleito, dentro do próprio palácio presidencial de La Moneda. O golpe militar chileno foi orquestrado pela junta militar comandada por Augusto Pinochet. Assim como as demais ditaduras do Cone Sul, o regime militar chileno se caracterizou pela extrema violência contra seus opositores (ANTUNES, 2008; AGGIO, 2008, PEREIRA, 2010 ).

Do ponto de vista da legalidade, os militares chilenos aboliram a Constituição, estabeleceram um estado de sítio em todo o território e executaram centenas de pessoas sem julgamento prévio. O Exército chileno assumiu o controle da maior parte do território. A prática da tortura era comum nos interrogatórios e os acusados eram julgados por tribunais militares "de tempos de guerra", onde as sentenças eram rapidamente cumpridas, sobretudo nos casos de pena de morte. Os principais alvos eram as pessoas suspeitas de apoiar Salvador Allende e membros dos partidos socialistas e comunistas. A cidade de Santiago foi o principal foco das ações repressivas, mas as mortes e desaparecimentos ocorreram em todo o território chileno (PEREIRA, 2010; ATRIA, 1989). 
Segundo Pereira (2010) o regime militar chileno, se comparado ao caso brasileiro, estava pouco preocupado com a atuação das forças armadas dentro dos limites da legalidade, sobretudo nos cinco primeiros anos após o golpe militar. "Nos primeiros meses após o golpe, o número das pessoas sumariamente executadas pelo Exército ou pela polícia (carabineros) parece ter sido muito superior ao das que receberam algum tratamento judicial" (PEREIRA, 2010, p. 60). Os julgamentos eram rápidos e as sentenças, embora severas, eram sumariamente aplicadas. Não havia direito de recurso para os réus, pois a Suprema Corte se recusava a rever os vereditos dos julgamentos realizados em tribunais militares.

Após a instituição do golpe militar chileno, foram criados órgãos de inteligência que tinham como objetivo assegurar a permanência do novo regime e reprimir os grupos opositores ou que poderiam apresentar alguma resistência ao regime. Nesse contexto surge a Dirección de Inteligencia Nacional (DINA), no final de 1973. Tratava-se de um órgão autônomo, centralizado e subordinado diretamente ao governo que estava sob o comando do coronel Manuel Contreras. O mesmo decreto que criou a DINA permitia a Junta Militar chilena convocar os demais serviços de segurança para participarem das ações do órgão, dando-lhe poderes para realizar prisões e buscas de prisioneiros em todo o país. Vale ressaltar que a Central Intelligence Agency (CIA), agência de inteligência dos EUA, foi responsável pelo treinamento de muitos membros da DINA, além da destinação de recursos financeiros para o órgão (ANTUNES, 2008).

Após a sua instalação, a DINA foi responsável pela repressão, pelos interrogatórios, pela classificação e separação das pessoas que seriam presas nos centros de detenção, acusadas de subversão ou de opositores ao regime militar. A existência de uma rede de colaboradores nos setores públicos, nos meios de comunicação e nos serviços de inteligência e segurança no exterior com as atividades da DINA possibilitou maior eficiência no êxito das ações repressivas adotadas por este departamento. Além disso, vários de seus membros receberam treinamentos da Coréia do Sul, do Irã, Alemanha, Estados Unidos e Israel.

A DINA mantinha centros de reclusão clandestinos, onde a prática de tortura contra os prisioneiros era comum. Em 1975 a DINA sediou o sistema da Operação Condor, cooperação entre os regimes militares do Cone Sul inicialmente integrada pela Argentina, Uruguai, Paraguai, Bolívia e Chile (ARQUIVOS DO TERROR, 1975; ANTUNES, 2008).

\section{A ESTRUTURA DA CONDOR}

Em agosto de 1975, durante a XI Conferência dos Exércitos Americanos, em Montevidéu, ocorreu uma reunião entre os comandantes das forças armadas e das polícias políticas dos países do Cone Sul para tratar dos assuntos relativos a criação da Operação Condor. Em outubro do mesmo ano, sob a liderança do coronel Manuel Contreras, ocorreu a reunião inaugural da Condor, em Santiago. De acordo com documentos encontrados nos 
Arquivos do Terror ${ }^{11}$, localizados no Centro de Documentação e Arquivo para a Defesa dos Direitos Humanos (CDyA) do Supremo Tribunal de Justiça do Paraguai, o objetivo principal da Operação Condor era a cooperação internacional entre os serviços de segurança dos países membros ${ }^{12}$ para perseguir e capturar subversivos políticos e "terroristas" de todas as nacionalidades. A estratégia foi ampliada para eliminar todos os opositores dos regimes militares, inclusive líderes militares e políticos civis, refugiados na América do Sul, América do Norte e Europa (DINGES, 2005).

Os fundamentos ideológicos que sustentavam esta estratégia se baseavam na luta contra a subversão e contra a "guerra psicopolítica" que ameaçam a "história, a filosofia, a religião e os costumes próprios dos países do hemisfério sul" (ARQUIVOS DO TERROR, 1975). Segundo o texto da ata da primeira reunião de trabalho da inteligência nacional, esta situação de ameaça aos bons costumes e a paz social "não reconhece fronteiras nem países, a infiltração penetra todos os níveis da vida nacional” (ARQUIVOS DO TERROR, 1975). Para eliminar essa ameaça, os representantes dos países membros propunham a criação de uma coordenação internacional que permitia a troca de informações e experiências entre os chefes dos serviços de segurança nacional. A troca de experiências contou com a expressiva participação dos dirigentes militares brasileiros que, após o golpe militar de 1964, disseminaram práticas repressivas por todos os países do Cone Sul (torturas, esquadrões da morte, sequestro e desaparecimento de pessoas) (PADRÓS, 2009).

Para materializar as trocas de informações entre os países membros da Condor, foi proposto a criação de um banco de dados, que funcionaria como centro de coordenação e segurança no Chile para recolher, trocar e comunicar informações sobre pessoas e organizações ligada à subversão. "Establecer en un país de los que aqui se encuentran representados, un Archivo Centralizado de Antecedentes de Personas, Organizaciones y otras Actividades, conectadas directa o indirectamente con la subversión” (ARQUIVOS DO TERROR, 1975).

Este banco de dados seria "similar à INTERPOL em Paris, mas dedicado à subversão". A alimentação e o financiamento deste banco de dados ficariam ao encargo dos Serviços de Segurança dos Países interessados, de acordo com o "Regulamento Orgânico e de Funcionamento" aprovado pelos delegados dos países membros da operação (ARQUIVOS DO TERROR, 1975).

\footnotetext{
${ }^{11}$ Foi realizada uma pesquisa ao acervo do Arquivo do Terror no Centro de Documentación y Archivo para la Defensa de los Derechos Humanos (CDyA) da Corte Suprema de Justiça do Paraguai em abril de 2013. Toda a documentação dos Arquivos do Terror encontra-se digitalizada. A seleção da documentação foi feita através da busca por palavras-chaves, tais como: reclusão ninõs, mujeres embarazadas, hijos em prisión, hijo detido recluido, ninõ detido recluido, chico detido, niños brasileño de reclusos, niño subversivo, prontuários, testemonios de niños secuestrados, azotes al niños, nalgadas al niños, violación de menores, menores de edad hijos de dirigentes políticos, nino nacido em cautiveiro, detenido político recluido. Além disso, durante a visita ao Paraguai procurou-se informações na Comision de Verdad y Justicia do Paraguai sobre mulheres que foram detidas grávidas durante a ditadura militar paraguaia. Os nomes revelados pela Comision foram pesquisados e encontrados nos registros dos Arquivos do Terror. Ao todo foram coletados, selecionados, organizados e classificados cerca de 450 documentos pela pesquisadora.

${ }^{12}$ Argentina, Paraguai, Uruguai, Chile e Bolívia. Somente em 1976, o Brasil se tornou membro da Operação Condor.
} vol.10, nº. 03, Rio de Janeiro, 2017.pp. 1398-1431 
A fim de que o sistema de informação funcionasse de forma eficaz ele deveria contar com o que existia de mais moderno em termos de tecnologia na época. Assim, na troca de informações os agentes de segurança contavam com instrumentos como telex, computadores, microfilmes, criptografia, correios, o que garantia rapidez e eficiência no serviço prestado (ARQUIVOS DO TERROR, 1975). A figura a seguir ilustra o esquema orgânico proposto na reunião inaugural da Operação Condor pelos delegados participantes.

Figura 1: Sistema de Coordenação da Operação Condor

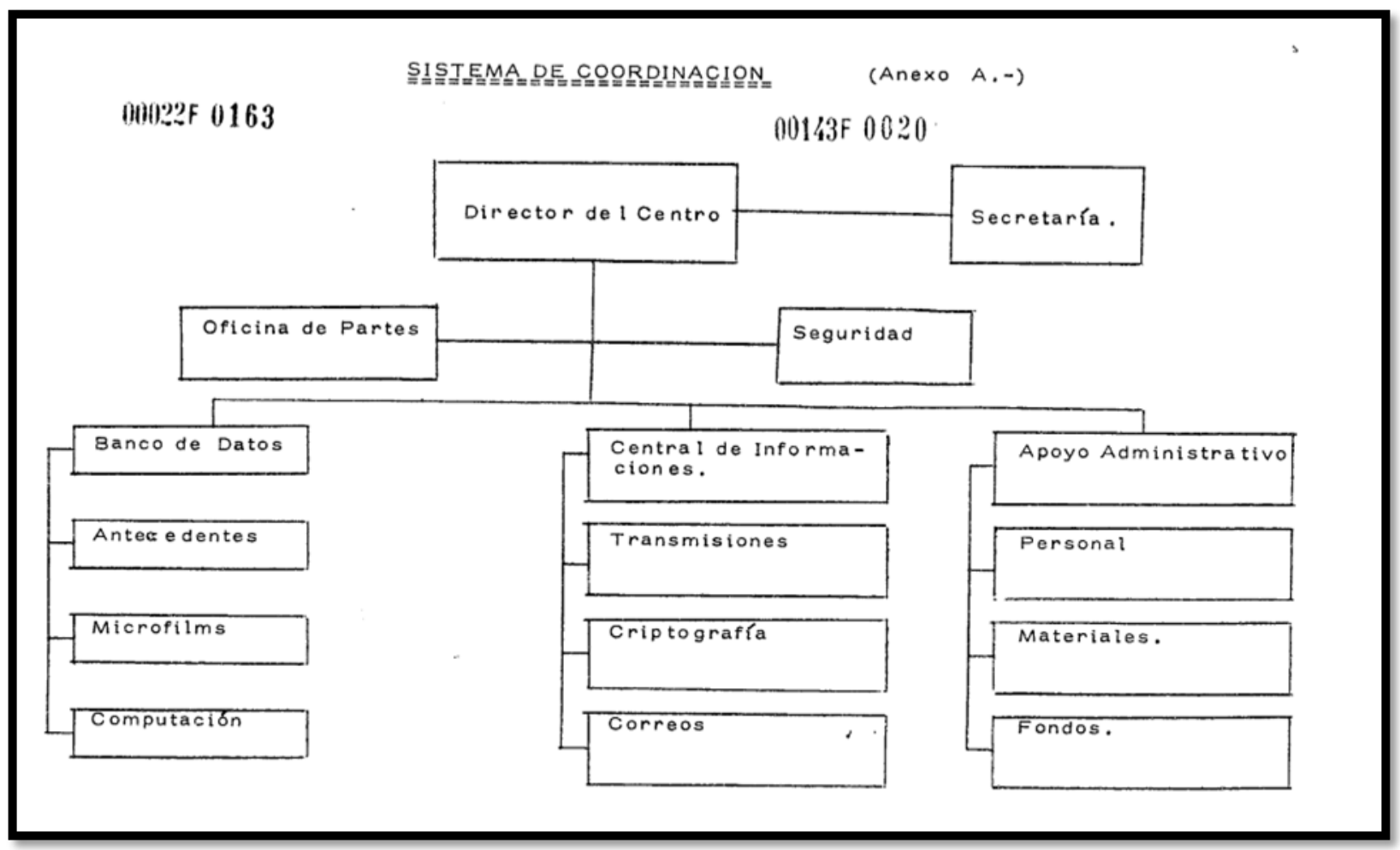

Fonte: ARQUIVOS DO TERROR. Primera Reunion de Trabajo de Inteligencia Nacional. Centro de Documentação e Arquivo para a Defesa dos Direitos Humanos (CDyA) do Supremo Tribunal de Justiça do Paraguai, 1975.

Além dessa rede de informações, os países membros realizaram reuniões de trabalho bilaterais ou extraordinárias sempre que a situação exigia. O banco de dados, a Central de Informações e as Reuniões de Trabalho formaram o sistema de Coordenação de segurança proposto pelos delegados dos países membros da Operação Condor (ARQUIVOS DO TERROR, 1975).

O sistema telex era o meio de comunicação mais comum utilizado entre as agências de segurança dos países membros da Condor. A medida que os subversivos e seus aliados viajavam de país para país, informações sobre o seu paradeiro e suas atividades eram introduzidas no banco de dados central e repassada para os demais países. Cada país fornecia e recebia as informações através do sistema de comunicação. A ata da primeira reunião da Condor apresenta a mecânica de consulta proposta para o funcionamento do sistema de comunicação (ARQUIVOS DO TERROR, 1975). 
Figura 2: Mecânica de Consulta Operação Condor

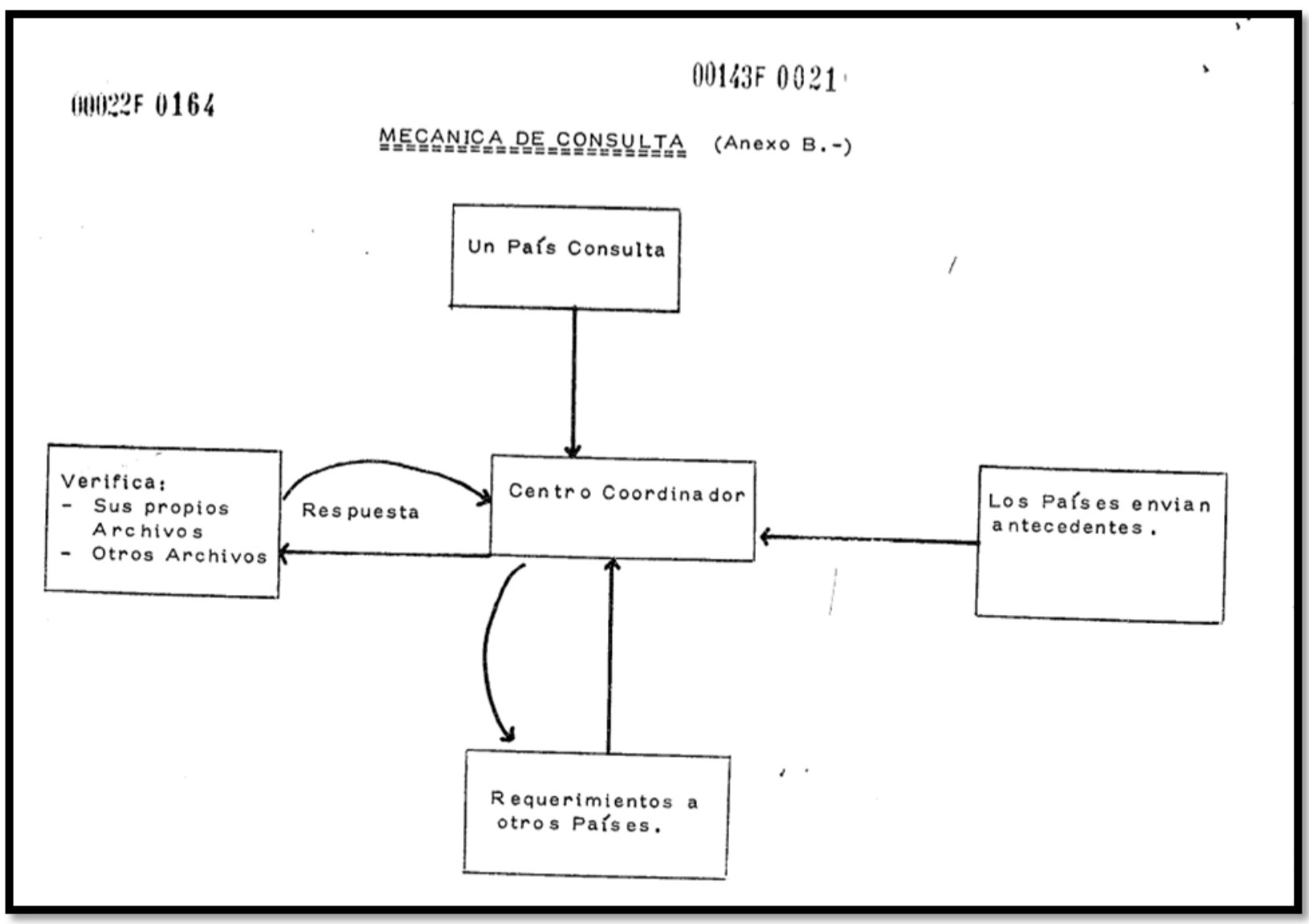

Fonte: ARQUIVOS DO TERROR. Primera Reunion de Trabajo de Inteligencia Nacional. Centro de Documentação e Arquivo para a Defesa dos Direitos Humanos (CDyA) do Supremo Tribunal de Justiça do Paraguai. 1975.

Segundo a ata da reunião inaugural da Operação Condor, poderiam integrar a organização todos os países que não fossem aliados dos países marxistas ou comunistas. A submissão a integração de novos países estava sujeita ao regulamento do sistema (ARQUIVOS DO TERROR, 1975).

A sede da organização era a DINA, Direção de Inteligência Nacional, em Santiago, Chile. A direção do sistema era exercida em comum acordo com os países membros, de forma rotativa, através de eleições e por um período determinado. A candidatura dos países ao cargo de direção do sistema ocorria de forma igualitária e proporcional a ajuda desse país para manutenção da organização. Os técnicos utilizados na operação tinham imunidade diplomática e eram selecionados de acordo com os serviços voluntários prestados, mediante prévia investigação de confiabilidade (ARQUIVOS DO TERROR, 1975). 


\section{AS FASES DA CONDOR}

Durante sua existência, a Operação Condor teve três fases. A primeira, descrita com detalhes na ata da reunião inaugural da Condor, era dedicada à formação de um banco de dados que continha informações sobre pessoas envolvidas com a subversão em todos os países do Cone Sul partícipes da operação. Além disso, foi prevista a criação de uma central de comunicações no Chile para colher, trocar e comunicar dados sobre pessoas ou organizações ligadas à subversão, através de mensagens criptografadas e telefones com inversores de voz, além da realização de reuniões regulares entre os chefes de inteligência dos países membros (ARQUIVOS DO TERROR, 1975). Segundo Dinges (2005, p. 34), posteriormente, Manuel Contreras assumiu publicamente que a CIA e o FBI não só tinham conhecimento daquele sistema de comunicação do Serviço de Inteligência como também contribuíram para sua atualização e fizeram uso daquele banco de dados para localizar supostos "terroristas" (ARQUIVOS DO TERROR, 1976).

No início, as ações da Condor se limitavam à América Latina. Cada país membro permitia que as agências de Inteligência de outros países operassem dentro de suas fronteiras, capturando, interrogando e torturando exilados, refugiados e prisioneiros, e, posteriormente, retornando com eles ao país de origem. Um dos mais conhecidos casos que comprova a existência da Operação Condor e sua forma de atuação foi o sequestro dos uruguaios Lílian Celiberti, refugiada em Porto Alegre, junto com seu companheiro Universindo Rodrigues Díaz e seus filhos Camilo de 8 anos e Francesca de 3 anos. Lilian e Universindo, que eram integrantes de organização de esquerda no Uruguai, estavam exilados no Brasil, preparando um dossiê de denúncia sobre violações dos direitos humanos no Uruguai. Os quatros foram detidos em seu apartamento pela força policial uruguaia, para aguardar a chegada de outros "supostos" subversivos (CUNHA, 2008).

A família foi feita refém em seu próprio apartamento sob a mira de agentes do Departamento de Ordem Política e Social do Rio Grande do Sul (Dops-RS) e do capitão Eduardo Ferro. O objetivo das forças de segurança do Brasil e do Uruguai era atrair Hugo Cores, líder do Partido da Vitória do Povo (PVP) em Montevidéu através de Lílian e Universindo. Contudo, ao perceber a armadilha, Cores ligou para redação da revista brasileira Veja e fez uma denúncia anônima sobre o desaparecimento do casal de uruguaios. Na tarde do dia 17 de novembro de 1978, um jornalista, Luiz Claudio Cunha, e um fotógrafo da revista Placar, João Baptista Scalco, foram até o apartamento onde os uruguaios estavam sendo mantidos como reféns, na capital gaúcha. Ao chegarem no apartamento das vítimas, eles se defrontaram com os policiais brasileiros e uruguaios e denunciaram o sequestro. Com a divulgação do caso na imprensa, o caso ganhou repercussão nacional e internacional (CUNHA, 2008, REIS, 2012). Este fato acabou evitando o desaparecimento do casal e de seus filhos. Mesmo assim, Lílian e Universindo foram condenados pela ditadura uruguaia a cinco anos de prisão, acusados de terem sido responsáveis por uma invasão falsa ao Uruguai (CUNHA, 2008; REIS, 2012). 
A segunda fase da operação foi marcada por ações conjuntas realizadas dentro dos países membros que possibilitaram a troca de prisioneiros sem qualquer registro oficial de entrada ou saída do país, bem como a localização de refugiados no exterior. Após vigiar e capturar os alvos, estes eram presos e submetidos a interrogatórios, geralmente com a prática da tortura. Os relatórios produzidos a partir dos interrogatórios eram compartilhados entre as forças de segurança dos países membros e os prisioneiros eram deportados para seus países de origem, onde eram detidos e muitos deles executados (DINGES, 2005). As operações dessa fase objetivavam atacar, incapacitar ou impedir a ação dos inimigos dos estados ditatoriais. Entre as ações promovidas incluem-se disseminação de propaganda que visavam desacreditar ou confundir o inimigo, localizar os possíveis alvos, capturar e prender os subversivos (ARQUIVOS DO TERROR, 1976).

Como os ativistas e militantes políticos, contrários as ditaduras militares, transitavam de um país para outro, ora como refugiados ou se escondendo, ora exilados ou banidos, era necessária uma cooperação entre os países membros da operação na localização, captura e prisão do inimigo. Sendo a Argentina o último país do Cone Sul a sofrer um golpe militar, muitos desses militantes e ativistas se refugiaram naquele país. Este fato talvez explique o número elevado de desaparecidos políticos ${ }^{13} \mathrm{e}$ de crianças sequestradas ${ }^{14}$ durante a segunda ditadura militar argentina, conforme dados das Abuelas de Praza de Mayo ${ }^{15}$.

Esta fase da Operação Condor aprimorou a colaboração entre os países membros, com agentes da segurança nacional trocando informações sobre ativistas oposicionistas e subversivos, com a captura dessas pessoas e posterior interrogatório. Após a detenção do inimigo, todos os países interessados poderiam participar do interrogatório. Os relatórios produzidos a partir dos interrogatórios eram compartilhados nos bancos de dados dos países e, caso fosse solicitado, o inimigo era transportado ao seu país de origem para novos interrogatórios e possível execução (ARQUIVOS DO TERROR, 1976). A citação a seguir faz referência ao depoimento de Dulce Chaves Pandolfi, ex-militante da Ação Popular Libertadora Nacional (ALN), presa em 14 de agosto de 1970, no Rio de Janeiro (RJ) e relata a participação de interrogadores de diferentes nacionalidades que procuravam obter informações através da prática da tortura.

Toda vez que o guarda abria a cela e vinha com aquele capuz, a gente já sabia que ia apanhar. Numa dessas vezes que foram me buscar, quando chego na sala de tortura, ao tirarem meu capuz percebo que era uma aula. Havia um professor e vários torturadores. Pelo sotaque, percebi que alguns não eram brasileiros, mas provavelmente uruguaios, argentinos. Então me disseram que eu era uma cobaia. Eles começaram a explicar como dar choque no pau de arara. Eu passei muito mal, comecei a vomitar, gritar. Aí me levaram para a cela e, dali a pouco, entrou um médico com outros torturadores. Ele me examinou, tomou minha pressão e o torturador perguntou: 'Como ela está?'. E o médico respondeu: 'Tá mais ou menos, mas ela aguenta'. E aí eles desceram comigo, sob gritos e protestos das companheiras de cela. A aula continuou e acabou comigo amarrada num poste no pátio com os olhos vendados, e os

\footnotetext{
${ }^{13}$ Cerca de 30.000 desaparecidos políticos.

${ }^{14}$ Cerca de 500 crianças sequestradas.

${ }^{15}$ Disponível em: https://www.abuelas.org.ar/abuelas/historia-9. Acesso em 5 fev. 2016.
} 
caras fazendo roleta russa comigo, no maior prazer. Essa brincadeirinha levou muito tempo, até que no sexto tiro a bala não veio. Na minha época, eu fui a única a servir de cobaia, acho que eles tinham uma 'predileção' especial por mim. No DOI-Codi, a barra foi pesadíssima. Teve pau de arara com choque elétrico no corpo nu: nos seios, na vagina, no ânus. Lá tinha um filhote de jacaré de estimação dos torturadores que eles colocavam para andar em cima do nosso corpo, amarrado numa cordinha. Fiquei três meses no DOI-Codi, depois fui para o Dops e, depois de um tempo, para o presídio de Bangu. Então, fui transferida para o presídio de Bom Pastor, em Pernambuco (Depoimento de Dulce Chaves Pandolfi, ex-militante da Ação Libertadora Nacional (ALN). Foi presa em 14 de agosto de 1970, no Rio de Janeiro (RJ) (MERLINO; OJEDA, 2010, p. 58).

Nesta citação, cuja prisão foi realizada em agosto de 1970, verifica-se a cooperação de agentes da segurança de diferentes nacionalidades na prática do interrogatório, cinco anos antes da criação oficial da Operação Condor. Este fato sugeri um envolvimento do Brasil na disseminação de práticas repressivas nos países do Cone Sul, utilizando de suas dependências clandestinas de interrogatórios como laboratórios de práticas de tortura e repressão e como foco disseminador das mesmas, assim como afirmou Padrós (2009, p.17). A tortura era uma prática comum nos interrogatórios. As informações conseguidas nos interrogatórios eram reproduzidas e transmitidas aos outros países para serem analisadas.

A terceira fase da Operação Condor envolvia a formação de equipes especiais dos países membros que viajavam a qualquer parte do mundo para assassinar "terroristas” ou aqueles que, segundo os órgãos da repressão, apoiassem organizações “terroristas”. A operação consistia em localizar um terrorista ou simpatizante no exterior, encaminhar uma equipe especial para vigiar o alvo e posteriormente, enviar uma segunda equipe para executar a "ação". A ditadura chilena de Pinochet realizou as principais ações dessa terceira fase da Operação Condor, planejando e executando assassinatos na Europa e nos Estados Unidos (ARQUIVOS DO TERROR, 1976).

A citação a seguir, referente a um cabograma enviado por Robert Scherrer $^{16}$, detalha o funcionamento da fase três da Operação Condor.

Uma terceira fase muito secreta da "Operação Condor" envolve a formação de equipes especiais dos países-membros, que devem viajar a qualquer país não-membro do mundo, a fim de executar sanções que chegam até o assassinato de terroristas ou defensores de organizações terrorista de países-membros da "Operação Condor". Por exemplo, se um terrorista ou um defensor de uma organização terrorista de um país-membro da "Operação Condor" fosse localizado em um país europeu, uma equipe especial da "Operação Condor" seria despachada para localizar e vigiar o alvo. Quando a operação de localização e vigilância terminasse, seria despachada uma segunda equipe da "Operação Condor" para executar a real sanção [assassinato] contra o alvo. Equipes especiais emitiriam documentação falsa de países-membros da "Operação Condor", e poderiam ser compostas exclusivamente de indivíduos de uma nação-membro da "Operação Condor", ou poderiam ser compostas de um grupo misto de várias nações-membros da "Operação Condor”. Dois países europeus mencionados especificamente para possíveis operações na terceira fase da "Operação Condor" eram a França e Portugal ${ }^{17}$ (DINGES, 2005, p. 288).

Um exemplo de operações da Condor na Europa, é o Plano Piloto Paris, orquestrado pela Argentina em

\footnotetext{
${ }^{16}$ Adido jurídico do FBI em Buenos Aires.

${ }^{17}$ La Paz 3254, 9 de maio de 1976, e La Paz 3657, 11 de maio de 1976 (Liberações Foia para Dinges).
} vol.10, nº. 03, Rio de Janeiro, 2017.pp. 1398-1431 
cooperação com França em 1977. O plano era uma combinação de ações repressivas entre os governos argentino e francês. Os objetivos do plano eram melhorar a imagem da Argentina na Europa, abrir um espaço político dentro dos meios de comunicação para favorecer o projeto político de Massera ${ }^{18}$, detectar militantes e dirigentes populares que estivessem no exterior. O plano era de caráter clandestino e realizava um trabalho paralelo ao do Centro de Difusion Argentino, criado mediante decreto do Ministério de Relações Exteriores, comandado pelo Vice-Almirante Montes. A marinha controlava a Chancelaria Argentina. Na produção do plano para o Centro de Difusão de Paris participaram: Vice-Almirante Montes (Ministro de Relações Exteriores), Capitão Gualter Allara (subsecretário de relações exteriores, Capitão Perez Froio (Sub-Secretário de Imprensa do Ministro de Relações Exteriores), Capitão Jorge Acosta (Chefe da GT 3.3/9), Capitão Jorge Perren (Chefe de Operações da GT 3.3/2), Tenente Pernía (Oficial da Inteligência da GT 3.3/2) (FUNDO CLAMOR. 1977).

Segundo Dinges (2005, p. 22), normalmente as vítimas da Operação Condor desapareciam. A partir de 1976, o Chile, a Argentina e o Uruguai resolveram criar equipes internacionais para os voos da Condor além das fronteiras com a América Latina. Experiências repressivas e capturas de subversivos políticos na América do Norte e na Europa passaram a fazer parte das ações dos integrantes da Operação.

\section{OS MÉTODOS DA CONDOR}

Um fato que contribuiu para aumentar o radicalismo das ditaduras no Cone Sul foi a cooperação dos governos civis-militares e autoridades diplomáticas na caça e captura de opositores dos regimes militares nesses países antes mesmo da criação da Operação Condor. Segundo Rabelo e Rabelo (2001, p. 158), o Brasil foi um dos primeiros países da América Latina a reconhecer o governo da junta militar chilena, presidida por Augusto Pinochet. Em 1973, o embaixador brasileiro no Chile, Antônio da Câmara Couto, coordenou a perseguição de exilados brasileiros naquele país. Ele ordenou que os funcionários da embaixada negassem visto aos familiares dos exilados que desejavam retornar ao Brasil e facilitou a ida de policiais brasileiros para o Chile para atuarem nos interrogatórios dos presos políticos detidos no Estádio Nacional chileno. "Logo após o golpe, o Ministério da Defesa chileno enviou ao governo do Brasil, uma lista dos brasileiros detidos no Estádio Nacional de Santiago e, também, uma outra lista dos que haviam se exilado na Embaixada argentina, na capital chilena" (PEREIRA, 2010, p. 151). Essas ações de dupla cooperação entre os países era o prelúdio do que seria a Operação Condor. No caso das mulheres, estupros e violências sexuais alteravam a rotina básica dos interrogatórios. O depoimento que se

\footnotetext{
${ }^{18}$ Emílio Eduardo Massera, militar argentino que pertencia a Armada Argentina. Entre 1976 e 1978 fez parte da junta militar que depôs a presidente Maria Estela Martínez de Peron, junto Jorge Rafael Videla e Orlando Ramón Agosti. Foi o responsável pela Escola de Mecânica do Exército (Esma), prisão clandestina onde foram executados cerca de três mil opositores do regime militar argentino.
} 
segue, de Gilse Cosenza, ex-militante da Ação Popular (AP), presa em 17 de junho de 1969, em Belo Horizonte (MG), subsidia essa informação.

Fomos colocadas na solitária, onde ficamos por três meses, sendo tiradas apenas para sermos interrogadas sob tortura. Era choque elétrico, pau de arara, espancamento, telefone, tortura sexual. Eles usavam e abusavam. Só nos interrogavam totalmente nuas, juntando a dor da tortura física à humilhação da tortura sexual. Eles aproveitavam para manusear o corpo da gente, apagar ponta de cigarro nos seios. No meu caso, quando perceberam que nem a tortura fisica nem a tortura sexual me faziam falar, me entregaram para uns policiais que me levaram, à noite, de olhos vendados, para um posto policial afastado, no meio de uma estrada. Lá, eu fui torturada das sete da noite até o amanhecer, sem parar. Pau de arara até não conseguir respirar, choque elétrico, espancamento, manuseio sexual. Eles tinham um cassetete cheio de pontinhos que usavam para espancar os pés e as nádegas enquanto a gente estava naquela posição, de cabeça para baixo. Quando eu já estava muito arrebentada, um torturador me tirou do pau de arara. Eu não me aguentava em pé e caí no chão. Nesse momento, nessa situação, eu fui estuprada. Eu estava um trapo. Não parava em pé, e fui estuprada assim pelo sargento Leo, da Polícia Militar. De madrugada, eu percebi que o sol estava nascendo e pensei: se eu aguentar até o sol nascer, vão começar a passar carros e vai ser a minha salvação. E realmente aconteceu isso. Voltei para a solitária muito machucada. A carcereira viu que eu estava muito mal e chamou a médica da penitenciária. Eu nunca mais vou esquecer que, na hora que a médica me viu jogada lá, ela disse: 'Poxa, menina, não podia ter inventado isso outro dia, não? Hoje é domingo e eu estava de saída com meus filhos para o sítio'. Depois disso, eles passavam noites inteiras me descrevendo o que iam fazer com a minha menina de quatro meses. 'Você é muito marruda, mas vamos ver se vai continuar assim quando ela chegar. Estamos cansados de trabalhar com adulto, já estudamos todas as reaçoes, mas nunca trabalhamos com uma criança de quatro meses. Vamos colocá-la numa banheirinha de gelo e você vai ficar algemada marcando num relógio quanto tempo ela leva para virar um picolé. Mas não pense que vamos matá-la assim fácil, não. Vocês vão contribuir para o progresso da ciência: vamos estudar as reações, ver qual vai ser a reação dela no pau de arara, com quatro meses. E quanto ao choque elétrico, vamos experimentar colocando os eletrodos no ouvido: será que os miolos dela vão derreter ou vão torrar? Não vamos matá-la, vamos quebrar todos os ossinhos, acabar com o cérebro dela, transformá-la num monstrinho. Não vamos matar você também não. Vamos entregar o monstrinho para você para saber que foi você a culpada por ela ter se transformado nisso'. Depois disso, me jogavam na solitária. Eu quase enlouqueci. Um dia, eles me levaram para uma sala, me algemaram numa cadeira e, na mesa que estava na minha frente, tinha uma banheirinha de plástico de dar banho em criança, cheia de pedras de gelo. Havia o cavalete de pau de arara, a máquina do choque, e tinha uma mamadeira com leite em cima da mesa e um relógio na frente. Eles disseram: 'Pegamos sua menina, ela já vai chegar e vamos ver se você é comunista marruda mesmo'. Me deixaram lá, olhando para os instrumentos de tortura, e, de vez em quando, passava um torturador falando: 'Ela já está chegando'. E repetia algumas das coisas que iam fazer com ela. O tempo foi passando e eles repetindo que a menina estava chegando. Isso durou horas e horas. Depois de um tempo, eu percebi que tinham passado muitas horas e que era blefe (MERLINDO; OJEDA, 2010, p. 192-193).

Neste depoimento em que a testemunha é detida em 1969, verificam-se técnicas similares de tortura adotadas nos países do Cone Sul, sobretudo após 1975, com a criação da Operação Condor, o que reforça o argumento de que o Brasil teria servido como laboratório das práticas repressivas e de dissimulação das mesmas.

Um documento comprovatório dessa prática é o Manual de Interrogatório encontrado no acervo do Departamento de Ordem Política e Social (DOPS), no Arquivo do Paraná (Brasil). Trata-se de um texto de 
autoria anônima, reproduzido e distribuído pelas polícias políticas estaduais e pelo Serviço Nacional de Informaçoes (SNI) ${ }^{19}$ durante a ditadura militar brasileira. Este documento pode ser dividido em três conteúdos básicos. O primeiro que aborda a conjuntura nacional brasileira com informações sobre o sistema educacional, a questão agrária, economia, política partidária, saúde e outros. Um segundo conjunto de informações refere-se a Segurança Nacional e aos inimigos internos da nação. E um terceiro conjunto de documentos, classificados como confidenciais, fornecia orientações para os agentes da repressão de quem deveria ser objeto de suspeita, de como informar os órgãos de segurança, de como classificar as informações e de quem eram os homens de confiança do Estado de exceção. Além disso, o manual do interrogatório instruía os agentes da segurança de como obter a confissão dos presos políticos através da coerção física ou psicológica (MAGALHÃES, 2004).

$\mathrm{Na}$ guerra travada contra a subversão e o comunismo, as ditaduras civis e militares adotaram uma sistemática metodologia de desaparecimento e assassinatos, protegida por dispositivos legais que impediam a defesa imediata dos indivíduos e posterior reconhecimento, baseados na certeza da impunidade e do esquecimento futuro (PADRÓS, 2009, p. 18).

Como o Estado de exceção não reconhecia a detenção dos cidadãos tidos como comunistas ou subversivos, estes ficavam sujeitos a vontade e a arbitrariedade dos sequestradores. Após a ocorrência dos assassinatos e torturas, os agentes da repressão tratavam de apagar os vestígios da detenção e eliminar os restos mortais das vítimas (DINGES, 2005).

Baseado nesta lógica e com a finalidade de ganhar tempo nas investigações, na busca e captura de subversivos e comunistas, os agentes da segurança e membros da equipe técnica da Operação Condor transformavam os interrogatórios em sistemáticas práticas de tortura. Para destruir a subversão, as ditaduras militares implantaram uma cultura do medo, da subserviência, da omissão e da delação disseminando imobilismo, desesperança e insegurança. A tortura, aplicada sistematicamente nos interrogatórios conduzidos pelos agentes da segurança dos países membros da Condor, "converteu a maioria dos seres humanos em bonecos soluçantes, fraturados e submissos sob o controle dos mestres interrogadores" (DINGES, 2005, p. 155).

Inúmeros métodos de tortura eram utilizados contra os opositores dos regimes militares durante os interrogatórios. Enforcamentos, afogamentos, asfixia, pau de arara $^{20}$, cadeira de dragão $0^{21}$, surras, coroa de cristo ${ }^{22}$, choque elétrico e geladeira eram os mais comuns. Além disso, durante os interrogatórios, os agentes da repressão

\footnotetext{
${ }^{19}$ Órgão vinculado à Presidência da República que coordenou a ação repressiva durante a vigência do regime militar brasileira.

${ }^{20} \mathrm{O}$ pau de arara consistia em uma barra de ferro presa a dois cavaletes; o preso era amarrado nu, com a barra de ferro atravessada entre seus punhos e joelhos. Normalmente esta técnica era completada com o uso choques elétricos nos órgãos genitais, palmatória, pancadas e queimaduras (BRASIL, 2009).

${ }^{21}$ A cadeira do dragão era uma cadeira revestida de zinco, onde os presos sentavam nus, com os pés e as mãos amarrados. Eram ligados fios elétricos ao seu corpo, transmitindo descargas na língua, ouvidos, olhos, pulsos, seios e órgãos genitais (BRASIL, 2009).

${ }^{22}$ A coroa de cristo era um torniquete de aço que ia sendo gradativamente apertado, esmagando o crânio do prisioneiro na região frontal e temporal (BRASIL, 2009).
} 
utilizavam familiares das vítimas, sobretudo filhos e filhas, como estratégia para obtenção de informações. O objetivo era desestruturar espiritualmente as prisioneiras, apelando para a sua situação de maternidade a fim de quebrar a resistência e o silêncio, obrigando-as delatar os companheiros em troca da vida e segurança dos filhos. Um desses casos, é o de Celsa Ramirez, detida grávida em 1975. Os registros de sua detenção encontram nos Arquivos do Terror. Durante o seu interrogatório ela teve sangramento e achou que tivesse perdido seu filho. Contudo, apesar das torturas sofridas ela conseguiu manter a gravidez. Seu filho Derlis Miguel Ramírez nasceu no hospital Rigoberto Caballero em 29 de novembro de 1975. Posteriormente ao nascimento, ambos foram detidos novamente no centro de detenção Fernando de Mora e ficaram presos até o dia 10 de agosto de 1978. Em seu testemunho dado à Comissão da Verdade e Justiça do Paraguai, ele diz não se recordar muito do tempo que passou na prisão. Ele só ficou sabendo da história de seus pais aos 8 anos, quando sua mãe lhe contou a história de seu pai biológico. Segundo ela, seu nascimento pode ser considerado um milagre, devido as torturas que sua mãe sofreu enquanto esteve presa. Contudo, o medo do retorno daqueles dias de repressão e tortura ainda permanece entre eles. Sua mãe ainda insisti na necessidade deles terem documentos de outros países para poder se refugiar, caso aqueles tempos macabros voltem a acontecer. Além disso, eles tem dificuldade de realizar projetos futuros e planejar suas vidas pensando a longo prazo. O depoimento a segue elucida essa informação.

Si pudimos llegar a eso es que puede volver a suceder, entonces el futuro se vuelve incierto si hay alguna represión y hay que escaparse. Mamá hasta ahora insiste que tenemos que tener documentos de otros países, se instala ese miedo permanente, es dificil imaginar proyectos de futuro y costó bastante tener proyectos a largo plazo como familia, porque era siempre la posibilidad que se desatara de vuelta una represión, tener mucha paranoia. Pero yo siento, sobre todo ahora, con este nuevo escenario que esas heridas se pueden ir curando ${ }^{23}$.

No poema que se segue, escrito por Janaína Teles quando tinha oito anos de idade e ia visitar seus pais Maria Amélia e César, ex-presos políticos, no presídio Romão Gomes em São Paulo, é possível perceber o sofrimento da criança ao ser brutalmente afastada de seus pais.

Dói o peito chorar.

Dói os seus olhos chorarem.

Dói nós viver.

Dói ver os outros chorarem.

Dói a natureza chorar.

Dói gostar dos outros.

Dói cair uma pedra no seu pé.

Dói falar tchau, amigos (apud JOSE, 2008).

Observamos neste poema um relato do sofrimento da criança que teve sua infância violada pela detenção, prisão e tortura de seus pais durante a ditadura militar brasileira. Ela e seus irmãos foram presos junto com seus pais e tiveram que presenciar a tortura dos mesmos. Esta prática era utilizada pelo aparelho repressivo,

\footnotetext{
${ }^{23}$ Dossiê de Dermis Miguel Ramírez, entrevista concedida à Comisíon de Verdade y Justicia do Paraguai no dia 11 de agosto de 2008 (Documento).
} 
sobretudo os CODI-DOI ${ }^{24}$, como técnica de interrogatório, visando obter informações sobre outros militantes políticos tratados como subversivos ou terroristas pelo Estado brasileiro (JOSE, 2008; BRASIL, 2009).

Segundo Carlos Fico (2001) essas técnicas e outras similares foram utilizadas pelo governo brasileiro e exportadas para o Chile e o Uruguai nos anos de 1970 conforme pode ser verificado no documento a seguir.

Para todos os brasileiros que tiveram oportunidade de manter contato com os oficiais de informações do exército argentino, chileno e uruguaio, é reconfortante ouvir o testemunho desses oficiais que, ao estudarem o nosso SISSEGIN, sentem que estamos certos e ficam admirados de ser ele uma criação inteiramente nossa. $\mathrm{O}$ Chile e o Uruguai adotaram em seus países um sistema semelhante ao nosso, adaptados às leis e às peculiaridades existentes em cada um deles. Os resultados da contra-versão e do contra-terrorismo são evidentes nesses dois países. A Argentina continua a combater a subversão e o terrorismo através de suas forças policiais e não tem tido os êxitos esperados em que pese todas as medidas sócio-econômicas, aliadas a outras de caráter liberal que aquela nação irmã vem adotado ${ }^{25}$ (apud FICO, 2001, p. 135)

No caso das mulheres, além da violência sexual, agressões e torturas sofridas, os abusos se estendiam para os seus filhos, sendo torturados e separados de suas mães logo após o nascimento. Muitas militantes grávidas sofreram abortos provocados durante os interrogatórios devido às torturas realizadas contra elas (ARNS, 1985). O depoimento da sobrevivente de um campo clandestino de detenção na Argentina subsidia essa informação.

As mulheres que eram presas grávidas ou chegavam de outros centros para dar à luz na ESMA representavam um dos maiores quadros de horror, de maior crueldade que pode planejar e levar a cabo um indivíduo; o choro de bebês misturado com os gritos de tortura (Nilda Goretta apud ARDITTI; LYKES, 1997, p. 109).

Vale ressaltar que, apesar da semelhança das técnicas de interrogatório empregadas pelos agentes de segurança dos países membros da Operação Condor, cada país tinha seus próprios métodos. No caso do Chile, os agentes da DINA eram seletivos na escolha dos prisioneiros. Normalmente as lideranças de movimentos opositores eram detidas e condenadas à morte ou ao desaparecimento (BRASIL, 2007).

O processo de investigação, captura e eliminação dos opositores dos regimes ditatoriais era sistemático. Primeiro os agentes da repressão levantavam informações sobre pessoas supostamente ligadas às organizações políticas clandestinas ou de oposição. Os prisioneiros eram vigiados, detidos e interrogados. Durante o interrogatório, através da prática da tortura, eles eram obrigados a fornecer nomes de outros companheiros, organizações e suas localizações. Essas pessoas eram presas e o sistema de delação via tortura se mantinha, visando desestruturar as organizações oposicionistas e desmobilizar os cidadãos. Com o avanço dos métodos de investigação e de captura, os agentes da repressão passaram a se infiltrar nas organizações de esquerda, passando

\footnotetext{
${ }^{24}$ Destacamento de Operações de Informações de Defesa Interna. Foi um órgão criado pelo Regime Militar Brasileiro para prender e torturar pessoas contrárias ao regime. Os agentes do DOI-CODI foram treinados na Escola Superior de Guerra (ESG) nos moldes da instituição americana Natianal War College, que prendia cidadãos que se opunha a hegemonia norte-americana durante a Guerra Fria.

${ }^{25}$ Sistema de Segurança Interna. SISSEGIN. Documento classificado como “secreto". [1974?]. Capítulo 2, fls. 44-45.
} vol.10, nº. 03, Rio de Janeiro, 2017.pp. 1398-1431 
informações sobre nomes de opositores do regime e de suas táticas de ação para toda a organização (BRASIL, 2007).

Um exemplo dessa prática foi a captura e morte da paraguaia Soledade Barrett Viedma, durante o massacre da Chácara São Bento, em Paulista (Recife - Brasil). Militante da Vanguarda Popular Revolucionária $(\mathrm{VPR})^{26}$, ela foi morta junto com mais seis companheiros numa emboscada preparada por seu companheiro, o cabo Anselmo, codinome Daniel, agente policial infiltrado na VPR. A versão oficial da ocorrência de um tiroteio foi desmentida pelas investigações posteriores. Os seis integrantes foram presos em diferentes locais e mortos sob tortura. Na época, a advogada de presos políticos Mércia de Albuquerque Ferreira teve acesso aos corpos e declarou que os olhos de Soledad estavam muito abertos, a boca entreaberta e tinha uma grande quantidade de sangue coagulado. Nos pés da vítima estava seu feto, filho de Soledad e do cabo Anselmo. A análise das fotos feita pelas forças de segurança no local demonstra que Soledad recebeu quatro tiros na cabeça e apresentava marcas de algemas nos pulsos. Ela foi enterrada como indigente sem qualquer identificação no cemitério de Várzea, em Recife (MERLINO; OJEDA, 2010, p.84-86).

Além dessas técnicas de interrogatório, muitos prisioneiros eram liberados para posterior simulação de acidentes e eliminação dos vestígios da detenção e tortura. Durante muitos anos, os crimes contra os direitos humanos cometidos pelos agentes da segurança e pela equipe técnica da Operação Condor, sob controle e manipulação diretos dos chefes de Estado e ministros de governo, foram sistematicamente negados. A existência de violações dos direitos humanos, de tortura e assassinatos como instrumentos da política oficial para eliminação do inimigo interno eram tratados como incidentes isolados de funcionários anômalos (BRASIL, 2007; (MERLINO; OJEDA, 2010).

\section{AS FORMAS DE RESISTÊNCIA}

A existência de regimes autoritários na América do Sul provocou a existência de repressão, exílios, prisões, tortura, mortes, sequestros e desaparecimento forçado. Apesar das dificuldades em apurar os fatos, estes acontecimentos levaram à reação das sociedades civis que exprimiram seu descontentamento de diversas formas, dentre elas: os movimentos dos refugiados políticos, as manifestações de rua, os movimentos estudantis, a luta armada, as organizações de esquerda, os movimentos pela anistia, os movimentos de familiares e desaparecidos políticos, os

\footnotetext{
${ }^{26}$ A VPR foi criada em 1968, resultante da fusão entre uma ala esquerda da Política Operária (Polop) e remanescentes de grupos militares de inspiração brizolista. Em junho de 1969, fundiu-se com o Colina (Comando de Libertação Nacional) de Minas Gerais, resultando na constituição da VAR-Palmares. Em setembro deste ano, ocorreu uma nova divisão na organização com o ressurgimento da VPR, que passou a ter como principal líder Carlos Lamarca. Em janeiro de 1973, houve uma tentativa de rearticulação da organização que foi abortada pelo massacre na chácara São Bento (BRASIL, 2007).
} 
movimentos em defesa dos direitos humanos, as Madres e Abuelas de Praza de Mayo, os integrantes do grupo Clamor.

Em março de 1980, um grupo de refugiados políticos argentinos no exílio divulgou os resultados de um estudo feito sobre a situação dos detidos e desaparecidos políticos na Argentina, baseado nas denúncias de exprisioneiros dos campos de detenção argentinos, coletadas durante um ano e seis meses. As informações do estudo realizado foram enviadas a Divisão de Direitos Humanos das Nações Unidas, para a Comissão Interamericana de Direitos Humanos da OEA, para a Anistia Internacional e outros organismos de defesa dos direitos humanos. Em fevereiro de 1980, veio a público os depoimentos de Oscar Alfredo Gonzalez e Horacio Cid de La Paz, ambos argentinos e residentes na Holanda, sobre os quinze meses que passaram detidos nos campos de concentração argentinos até o dia 18 de janeiro de 1979, quando conseguiram sair. De acordo com esses depoimentos a quase totalidade dos prisioneiros políticos foi assassinada nos centros de detenção. $\mathrm{O}$ uso das práticas de tortura era maciço e sistematicamente aplicado pelas forças armadas e de segurança. No caso dos dois ex-prisioneiros, a delação de alguns companheiros e a tortura de outros, com suas próprias mãos, foi o preço que pagaram pela sua liberdade, a fim de que continuassem sendo um instrumento da ditadura argentina no exterior (FUNDO CLAMOR, 1980). Segundo Calveiro (2013), a delação dos companheiros debilitava e humilhava os delatores e os demais prisioneiros. Quando isso acontecia, os guardas propagavam o ocorrido, causando sofrimento, apreensão e angústia nos demais presos. Era uma prova irrefutável que a repressão estava vencendo e conseguindo quebrar a resistência dos prisioneiros. A delação de outros militantes garantia que os campos de concentração funcionassem e alcançassem seus objetivos: a desestruturação do ser humano e a imobilidade da sociedade civil.

Elas orientaram o trabalho dos interrogadores, ajudavam a aumentar sua eficiência: a saber o que deveriam perguntar, como fazê-lo, quais eram as debilidades de uma pessoa. Enfim, foram de grande utilidade e representaram o tipo de sujeito que o campo de concentração e a tortura produzem: medrosos, submissos, autoritários, instáveis (CALVEIRO, 2013, 78).

Segundo depoimentos desses presos, houveram vários "translados" de prisioneiros políticos no período em que estavam detidos. Os "translados" possuíam um duplo significados para os detidos: terror e esperança. Os guardas comunicavam-lhes que seriam transferidos para outros centros de detenção sem especificar seu destino. Suas roupas e pertences eram deixados para trás e posteriormente incinerados. Geralmente os prisioneiros eram dopados com uma substância que os deixava inconscientes. Antes de serem "transladados" recebiam uma boa alimentação, eram obrigados a se banhar e fazer a higiene. Os guardas os preparavam para uma última cena: a do seu fuzilamento. Na versão oficial, os prisioneiros apareciam como mortos em tiroteios ou em enfrentamentos entre si. O depoimento a seguir subsidia essa informação.

En nuestros 15 meses de desaparecidos fuimos testigos de aproximadamente una decena de traslados. El primero que presenciaríamos fue el del 17/11/77 (...) Desde mediados de 1977 dejaban sin venda a los presos más antigos para realizar las tareas de limpeza y 
mantenimiento interno. En el "Club Atlético" los "destabicados" eran entre 8 y 10; en el "Banco" oscilaban entre 15 y 20. A fines de enero de 1978 também nosotros fuimos sacados a trabajar. (...) El conjunto de las informaciones que aquí volcamos demuestra que una inyección de una flerte droga era aplicada a todos os companeros transladados. Su efecto era la inconciencia (FUNDO CLAMOR, 1980.s/p.).

Apesar dos meios de comunicação oficiais negarem essas brutalidades promovidas pelos governos autoritários dos países no Cone Sul, a sociedade civil, sobretudo os familiares dos mortos e desaparecidos políticos durante o período dos regimes militares insistiram em obter informações sobre seus entes queridos. A solidariedade gerada em torno desses fatos possibilitou a formação de diversas organizações de direitos humanos na Argentina e nos demais países. Uma das mais expressivas, tendo em vista a dimensão do trabalho realizado e seu efeito na sociedade e na identidade argentina, são as organizações das Madres e das Abuelas de la Plaza de Mayo. Estas organizações, graças ao trabalho incessante e incansável das mães e avós dos desaparecidos políticos, conseguiram obter informações de seus filhos executados e resgatar várias crianças apropriadas de forma ilegal pelos agentes da repressão. As integrantes dessas associações, baseadas nos direitos de mães e avós, exigiram do Estado argentino explicações dos fatos acontecidos. Suas ações ganharam notoriedade pública nacional e internacionalmente, obrigando o Estado argentino a prestar esclarecimento a respeito dos desaparecimentos, sequestros e apropriações ilegais. Contudo, as mães e avós da praça de maio não se conformaram com as informações destorcidas fornecidas pelo Estado e continuam denunciando as atrocidades cometidas pelos agentes da repressão e pelos dirigentes dos Estados ditatoriais. Com o passar do tempo elas foram conquistando a solidariedade de diversas organizações de direitos humanos na realização de suas ações, na concretização de suas buscas e na efetivação das denúncias nos países da América do Sul, Europa e Estados Unidos. Um dessas organizações foi o Comitê de Defesa dos Direitos Humanos para os países do Cone Sul, CLAMOR.

O Comitê de Defesa dos Direitos Humanos para os países do Cone Sul (CLAMOR) foi uma organização civil, informal e clandestina, criada no final do ano de 1978, com o apoio do Cardeal Arcebispo Dom Paulo Evaristo Arns, na cidade de São Paulo. No período da sua fundação, o Comitê era com composto por três pessoas ligadas a defesa dos direitos humanos - a jornalista Jan Rocha, o advogado Luiz Eduardo Greenhalgh e o pastor Jaime Wright. Os três se reuniram em São Paulo para verificar a possibilidade de divulgação das atrocidades cometidas contra os direitos humanos dos argentinos, uruguaios, paraguaios, chilenos e brasileiros durante o regime militar desses países. Procuraram o Cardeal Arcebispo Dom Paulo Evaristo Arns para comunicar a vinda maciça de refugiados políticos que relatavam histórias de violação dos direitos humanos. Dom Paulo acolheu a ideia e solicitou que o Comitê, por motivos de segurança, permanecesse vinculado a Comissão Arquidiocesana de Pastoral dos Direitos Humanos e Marginalizados, da Arquidiocese de São Paulo. Naquele momento, nascia o Comitê de Defesa dos Direitos Humanos dos Países do Cone Sul.

O objetivo dessa organização era denunciar as violações de direitos humanos que vinham ocorrendo na 
América Latina, sobretudo no Brasil, Uruguai, Argentina, Chile e Paraguai, além de prestar auxílio aos refugiados e perseguidos políticos. No depoimento que se segue, a ex-presa política relata a intervenção de Dom Paulo Evaristo Arns como responsável pela sua libertação e pelo término de seu interrogatório feito sob tortura.

Era muita gente em volta de mim. Um deles me deu pontapés e disse: 'Você, com essa cara de filha de Maria, é uma filha da puta'. E me dava chutes. Depois, me levaram para a sala de tortura. Pediram que eu me despisse, eu falei que não ia tirar a roupa. O outro disse: 'Ou você tira ou tiramos nós'. Fiquei em dúvida entre a humilhação de ser despida por eles ou eu mesma me despir. Foi muito humilhante ter de tirar a roupa. Aí, começaram a me dar choques direto da tomada no tornozelo. Eram choques seguidos no mesmo lugar. Havia um desprezo por parte deles. Junto com a ideologia, vinha essa humilhação pelo fato de ser mulher, como se a gente estivesse extrapolando nosso papel de mulher. O tom era de 'por que você não está em casa, ao invés de estar aqui? Por que você perde tempo com coisas que não lhe dizem respeito?'. Era como se você merecesse ser torturada porque estava fazendo o que não devia ter feito. Um deles me perguntou: 'Por que você se mete com esses padres revolucionários, com esse pessoal?'. Eu tinha sido presa junto com o Giulio Vicini, que na época era padre. A minha tortura no Dops foi interrompida, e um dos homens disse: 'Você foi salva pelo gongo'. Na madrugada, fiquei sabendo que o dom Paulo Evaristo Arns intercedeu em nosso favor. Logo nos encaminharam ao Presídio Tiradentes. A atuação de dom Paulo foi direta e imediata. Ele pediu que fizéssemos um relato da tortura sofrida. $\mathrm{Na}$ semana seguinte mandou ler em todas as igrejas de São Paulo um comunicado contendo a denúncia de nossa tortura ${ }^{27}$ (MERLINO; OJEDA, 2010, p.95).

A imagem que marcava o símbolo do Clamor era um desenho de uma chama que brilha através das grades de uma prisão, criado pelo preso político Manoel Cirilo de Oliveira Neto, que foi libertado em 1979. Além do símbolo, o Comitê também possuía um slogan "Direitos Humanos não tem fronteiras" (FUNDO CLAMOR, 1990). Com esse slogan o Comitê percorreu todos os países do Cone Sul e buscou auxílio financeiro e político junto aos organismos internacionais como o Conselho Mundial das Igrejas, a Anistia Internacional, Nações Unidas e Banco Mundial. Segundo Padrós (2009, p. 30-31),

o CLAMOR se configurou como uma estrutura de contrapeso da Operação Condor, pois possibilitou uma espécie de rede de informação em defesa das vítimas dos regimes autoritários. Mas, ao contrário da conexão repressiva que produzia morte, ação do CLAMOR salvava vida e lutava para reencontrar crianças roubadas das suas famílias.

Segundo relatos e testemunhos registrados no Fundo Clamor, havia listas de adoções nos presídios para os bebês que nasceram de prisioneiras detidas grávidas. As mulheres eram torturadas e, após o parto, geralmente eram executadas e suas crianças eram entregues para a adoção, muitas delas para famílias de militares que participaram do assassinato de seus pais biológicos. O trabalho dos integrantes do grupo Clamor ajudou a localizar vinte e sete crianças desaparecidas durante os regimes militares do Cone Sul, cujas denúncias chegaram até ao Comitê através dos auxílios prestados aos refugiados políticos. Durante a sua atuação o grupo conseguiu compilar uma lista de 163 crianças desaparecidas e apropriadas conforme denúncias recebidas (FUNDO CLAMOR, 1990).

\footnotetext{
${ }^{27}$ Yara Spadini, foi torturada e presa junto com outros padres. Após sua libertação, o testemunho da tortura que ela sofreu foi denunciado em todas as igrejas de São Paulo.
} 
Em outubro de 1990, após o retorno político da democracia no Brasil o grupo interrompeu suas atividades na certeza de que seu trabalho de denúncia e auxílio àqueles que não tinham voz na arena política possa ser continuado pelas organizações locais. O grupo CLAMOR, que foi "entidade-meio para as denúncias daqueles que não tinha voz e vez, interrompe suas atividades com a tranquilidade de consciência do dever cumprido" (FUNDO CLAMOR, 1990, p.5).

Em 1993, grande parte do acervo documental do grupo CLAMOR foi incorporado ao Centro de Documentação e Informação Científica da Pontifícia Universidade Católica de São Paulo, na cidade de São Paulo. Desde então o Fundo Clamor tem sido objeto de pesquisas para variados fins: desde pesquisas acadêmicas até pesquisa de documentos para comprovação de direitos.

\section{CONSIDERAÇÕES FINAIS}

O objetivo deste manuscrito foi descrever a estrutura e métodos de funcionamento da Operação Condor, bem como algumas formas de resistências desenvolvidas pelas sociedades civis do Cone Sul às suas ações. Criada em 1975, sob a liderança do coronel Manuel Contreras, a Operação Condor representou o auge das ações da Dirección de Inteligencia Nacional (DINA) e tinha como finalidade a troca de informações e conhecimento sobre os agentes e ativistas opositores dos regimes civis militares vigentes no Cone Sul durante a segunda metade do século XX. O astuto e preciso voo da Condor ultrapassou os limites nacionais e alcançou suas presas mesmo em territórios estrangeiros. Era preciso a utilização de estratégias camaleônicas para disfarçar os refugiados políticos e garantir a sua integridade física, como as desenvolvidas pelos integrantes do grupo Clamor.

Durante a sua existência, a "Operação Condor" contribuiu para a prisão, tortura, morte e desaparecimento de centenas de cidadãos e ativistas políticos no Cone Sul. Uma das principais vítimas das ações repressivas promovidas contra os opositores políticos dos regimes militares foram os jovens, principalmente os estudantes que integravam as manifestações ou as organizações clandestinas. Além dos jovens, outro grupo de vítimas da repressão foram as mulheres. Nesse grupo, além da aplicação de diversas técnicas de tortura geralmente aplicadas nos prisioneiros homens, o estupro das prisioneiras eram variações utilizadas como técnicas para obtenção das informações durante a realização dos interrogatórios. Entre os métodos empregados pela Condor destaca-se tortura de crianças e bebês que eram trazidos até as salas de interrogatório para presenciar a tortura de seus pais. Além disso, as práticas de sequestro e apropriação de crianças, filhas de prisioneiros políticos visavam intimidar os familiares e quebrar o silêncio dos pais, através da tortura de seus filhos.

Com a conivência das autoridades nacionais e internacionais, respaldada pelo compromisso de cooperação mútua firmado na Operação Condor, a partir dos anos 1970, os opositores dos regimes ditatoriais eram perseguidos, torturados e sistematicamente, eliminados. A guerra de contra insurgência, idealizada pela 
Doutrina de Segurança Nacional e seguida nos países do Cone Sul, não poupou esforços nem efetivos para eliminação dos inimigos internos e de seus familiares.

A análise dos acervos dos 'Arquivos do Terror" e do Fundo Clamor nos permitiu, a partir do ponto de vista histórico, reconstituir a memória de um passado recente cujas lembranças e testemunhos eram questionadas juridicamente. Atualmente esses documentos têm sido utilizados para comprovar as violações dos direitos humanos cometidas pelos agentes da segurança em nome do Estado ditatorial. Vale ressaltar que a descoberta dos arquivos secretos da polícia paraguaia possibilitou a comprovação de fatos sistematicamente negados pelos governos militares, tais como a existência da "Operação Condor" e o protagonismo brasileiro na troca de informações sobre prisioneiros políticos e técnicas de interrogatório, com estreita cooperação dos países do Cone Sul durante os interrogatórios. A análise dessa documentação permitiu que uma parte oculta das histórias paraguaia, chilena, argentina, uruguaia e brasileira viesse a público. As fontes oriundas desses acervos tornaram possível a abertura e revisão de processos judiciais movidos contra os Estados pela violação dos direitos humanos de milhares de cidadãos no Cone Sul, através da cooperação internacional repressiva.

Atualmente, todos os países do Cone Sul desfrutam, pelo menos, de uma década de regime democrático. Contudo o estado de direito democrático e o governo constitucional destes países vivem sob a sombra da impunidade. A veracidade destes relatos é constantemente questionada pela dificuldade de obtenção de provas e pela negativa dos acusados em cooperar com as investigações. Apesar disso, na Argentina e no Uruguai as usurpações dos direitos humanos por motivos políticos não mais encontram respaldo social e jurídico. Nos tribunais que julgam os casos de violações dos direitos humanos durante o período ditatorial prevalecem o testemunho dos sobreviventes dos centros clandestinos de detenção e dos familiares dos desaparecidos políticos.

Apesar da ferida aberta que essas violações de direitos humanos geraram nas sociedades sul-americanas, associações e organizações de direitos humanos destes países fizeram e fazem um trabalho sem igual de localização e restituição da identidade desses jovens e crianças desaparecidos vivos (sequestrados) e mortos (assassinados). Neste grupo destaca-se o trabalho das associações das Abuelas de Plaza de Mayo e do grupo Clamor, cujos registros documentais possibilitam a recuperação da memória de uma história manchada pelo desaparecimento de gerações passadas e futuras. Analisar esses documentos vai além de recontar suas histórias. É garantir aos cidadãos o direito à memória e ao conhecimento de fatos que necessitam ser relembrados e discutidos, para que nunca mais aconteçam, para que nunca mais se repitam. 


\title{
UNDER THE SIGHT OF THE CONDOR
}

\begin{abstract}
This article aims to describe the structure, methods and activities of Operation Condor during the term of military regimes in the Southern Cone. The methodology was the bibliographical research and documentary research, based at the crossroads of sources and evidence from various sources: official documents and military of the "Files of Terror" and "Clamor Fund".

The central argument of this research consists in the assertion that activities of security agents from Brazil, Paraguay, Argentina, Bolivia, Uruguay and Chile through participation in Operation Condor, was responsible for violating the human rights of thousands of citizens of these countries, increasing the number of politically disappeared during the military dictatorship period.
\end{abstract}

Keywords: Operation Condor. Military dictatorship. Human Rights. Southern Cone. Brazil.

\section{REFERÊNCIAS BIBLIOGRÁFICAS}

ABUELAS DE PLAZA DE MAYO. História. Disponível em: https://www.abuelas.org.ar/abuelas/historia-9. Acesso em: 10 jan. 2016.

AGGIO, Alberto. O Chile de Allende: entre a derrota e o fracasso. In: ARAUJO, Maria Paula Nascimento et al. Ditadura e Democracia na América Latina. Rio de Janeiro: Editora FGV, 2008. p.77-94.

ALVAREZ, Mario Rubén. Data Feliz no Paraguai: festejos de 3 de novembro, aniversário de Alfredo Stroessner. In: ROLLEMBERG, Denise; QUADRAT, Samantha (Orgs.). A construção social dos regimes autoritários: Brasil e América Latina. Rio de Janeiro: Civilização Brasileira, 2010. V.II. p. 393-433.

ALVES, Maria Helena Moreira. Estado e oposição no Brasil (1964-1984). Petrópolis: Vozes, 1989.

ANDRADE, Ana Célia Navarro. Inventário do Fundo Clamor: organização e descrição do Fundo Comitê de Defesa dos Direitos Humanos para os países do Cone Sul - Faculdade de Filosofia, Letras e Ciências Humanas, Universidade de São Paulo, São Paulo, 2000.

ANTUNES, Priscila. Ditaduras militares e institucionalização dos serviços de informações na Argentina, no Brasil e no Chile. In: ARAUJO, Maria Paula Nascimento et al. Ditadura e Democracia na América Latina. Rio de Janeiro: Editora FGV, 2008. p.201-244.

ARAÚJO, Maria do Amparo Almeida et al. Dossiê dos mortos e desaparecidos políticos a partir de 1964. Recife: Companhia Editora de Pernambuco, 1995.

ARDITTI, R; LYKES, M. B. (1997). La labor de las abuelas de Plaza de Mayo. In: ABUELAS DE LA PLAZA DE MAYO. Restituición de niños. Buenos Aires: Editorial Universitaria de Buenos Aires, 1997.

ARNS, Paulo Evaristo. Brasil: nunca mais. Petrópolis: Vozes, 1985.

ARQUIVOS DO TERROR. CHILBOM/CONDOR Centro de Documentação e Arquivo para a Defesa dos 
Direitos Humanos (CDyA) do Supremo Tribunal de Justiça do Paraguai. 28 set. 1976.

Primera Reunion de Trabajo de Inteligencia Nacional. Centro de Documentação e Arquivo para a Defesa dos Direitos Humanos (CDyA) do Supremo Tribunal de Justiça do Paraguai. 1975.

ATRIA, Rodrigo. Chile: la memoria prohibida. 4. ed. Santiago: Pehuén Editores, 1989.

BARRETO, Anna Flávia Arruda Lanna. Memórias da Resistência. Revista do Arquivo Público Mineiro. Belo Horizonte, Ano LI, n. 2, p. 86-111, jul.- dez. 2015.

Movimento Feminino pela Anistia: a esperança de retorno à democracia. Curitiba: CRV, 2011.

BRASIL. Presidência da República. Secretaria Especial dos Direitos Humanos. Direito à Memória e à Verdade: histórias de meninas e meninos marcados pela ditadura. Brasília: Secretaria Especial dos Direitos Humanos, 2009.

Presidência da República. Secretaria Especial dos Direitos Humanos. Direito à verdade e à memória: Comissão Especial sobre Mortos e Desaparecidos Políticos. Brasília: Secretaria Especial dos Direitos Humanos, 2007

Supremo Tribunal Federal. Glossário Jurídico: Habeas Data. Disponível em: http://www.stf.jus.br/portal/glossario/verVerbete.asp?letra=H\&id=156. Acesso em: 02 fev. 2016.

CALVEIRO, Pilar. Poder e Desaparecimento: os campos de concentração na Argentina. Trad. Fernando Correa Prado. São Paulo: Boitempo, 2013.

CATELA, Ludmila da Silva. Violencia política y dictadura en Argentina: de memorias dominantes, subterráneas y denegadas. In: FICO, Carlos; FERREIRA, Marieta de Moraes; ARAÚJO, Maria Paulo; QUADRAT, Samantha Viz (Orgs.). Ditadura e Democracia na América Latina: balanço histórico e perspectiva. São Paulo: FGV, 2008. p. $179-200$.

CUNHA, Luiz Cláudio. Operação Condor: o sequestro dos uruguaios, uma reportagem dos tempos da ditadura. Porto Alegre: L\&PM, 2008.

D'ARAÚJO, Maria Celina (Org.). Os anos de chumbo: memória militar sobre a repressão. Rio de Janeiro: Relume Dumará, 1994.

DINGES, John. Os anos do condor: uma década de terrorismo internacional no cone sul. São Paulo: Companhia das Letras, 2005.

DREIFUSS, René A. 1964: A Conquista do Estado. Ação Política, Poder e Golpe de Classe. Rio de Janeiro: Vozes, 1981.

FERNANDES, Ananda Simões. A reformulação da Doutrina de Segurança Nacional pela Escola Superior de Guerra no Brasil: a geopolítica de Golbery do Couto e Silva. Antíteses, vol. 2, n. 4, jul.-dez. de 2009, pp. 831-856. Disponível em: http://www.uel.br/revistas/uel/index.php/antiteses/article/viewFile/2668/3937. Acesso em: 30 jun. 2016.

FICO, Carlos. Como eles agiam: os subterrâneos da Ditadura Militar: espionagem e polícia política. Rio de Janeiro: Record, 2001

FILHO, Expedito. Autópsia da Sombra. Revista Veja, p. 20- 32, 18 de Nov. 1992. 
FRANCO, Bernardo Mello. Coronel admiti que torturou, matou e ocultou corpos na ditadura militar. Folha de São Paulo. 25 mar. 2014. Disponível em: http://wwwl.folha.uol.com.br/poder/2014/03/1430795-coroneladmite-que-torturou-matou-e-ocultou-corpos-na-ditadura-militar.shtml. Acesso em 25 jun. 2015.

FUNDO CLAMOR. CLAMOR: uma história de solidariedade. Centro de Documentação e Informação Cientifica CEDIC, da PUC/SP, Brasil. 1990.

Denúncia sobre la Situacion de los Detenidos-Desaparecidos en la Argentina. Caixa 11. Centro de Documentação e Informação Cientifica CEDIC, da PUC/SP, Brasil. Marzo, 1980.

Plano Piloto Paris. Caixa 13, plástico 7. Arquivo do Comitê de Defesa dos Direitos Humanos para os Países do Cone Sul, do Centro de Documentação e Informação Científica - CEDIC - Pontifícia Universidade Católica de São Paulo / SP. 1977.

GORENDER, Jacob. Combate nas Trevas: a esquerda brasileira: das ilusões perdidas à luta armada. São Paulo. Ática, 1987.

JOSÉ, Emiliano. A hora azul. Carta Capital. São Paulo. Sociedade. 27 out. 2008. s/p. Disponível em: http://www.cartacapital.com.br/sociedade/a-hora-azul. Acesso 20 maio 2016.

LIMA, Samarone. A Penumbra Compartida: a resistência solidária do grupo Clamor às ditaduras do cone sul da América Latina (1978-1991). 2000. 155 p. Dissertação (Mestrado em Integração da América Latina) Universidade de São Paulo, São Paulo, 2000.

Clamor: a vitória de uma conspiração brasileira. Rio de Janeiro: Objetiva, 2003.

LÓPEZ, Miguel H. "Stroessner e "Eu": a cumplicidade social com a ditadura (1954-1989)". In: A construção Social dos Regimes Autoritários: Legitimidade, consenso e consentimento no século XX Brasil e América Latina. Rio de Janeiro: Civilização Brasileira, 2010. p. 437-470.

MAGALHÃES, Marion Brepohl de. Documento: Manual do Interrogatório. História: Questões \& Debates, Curitiba, n. 40, p. 201-240, 2004.

MARIANO, Nilson. As garras do condor. Petrópolis: Vozes, 2003.

MARTINS FILHO, João Roberto. Os Estados Unidos, a Revolução Cubana e a Contra-insurreição. Revista de Sociologia e Política. N. 12. p. 67-82. Jun. 1999. Disponível em: http://www.scielo.br/pdf/rsocp/n12/n12a04. Acesso em: 30 jan. 2015.

MERLINO, Tatiana; OJEDA, Igor (Orgs). Direito à memória e à verdade: Luta, substantivo feminino. São Paulo: Caros Amigos, 2010.

NOVARO, Marcos; PALERMO, Vicente. A ditadura militar na Argentina: 1976-1983. São Paulo: Edusp, 2007.

PADRÓS, Enrique Serra. A Operação Condor e a conexão repressiva no Cone Sul: a luta pela verdade e pela justiça. Organon, Porto Alegre, n. 47, p. 115-138, jul./dez. 2009.

As escolas militares dos Estados Unidos e a pentagonização das Forças Armadas na América Latina.

$\overline{\text { Outros }}$ Tempos. v. 1 esp., 2007, p. 13-31. Disponível em: http://www.outrostempos.uema.br/vol_especial/dossieespecialart02.pdf Acesso em: 30 fev. 2015.

Como el Uruguay no hay... Terror de Estado e Segurança Nacional. Uruguai (1968-1985): do Pachecato à ditadura civil-militar. 2005. 434 f. Tese (Doutorado em História) - Instituto de Filosofia e Ciências 
Humanas, Universidade Federal do Rio Grande do Sul, Porto Alegre: UFRS, 2005.

PAZ, Alfredo Boccia. Los "Archivo del horror" del Paraguay: los papeles que resignificaron la memoria del stronismmo. In: FICO, Carlos; FERREIRA, Marieta de Moraes; ARAÚJO, Maria Paula; QUADRAT, Samantha Vaz (Orgs.). Ditadura e Democracia na América Latina: balanço histórico e perspectivas. Rio de Janeiro: FGV, 2008.p. 27-43.

PAZ, Alfredo BOCCIA; GONZÁLEZ, Myriam; AGUILAR, Rosa Palau. Es mi informe: Los archivos secretos de la Policía de Stroessner. Asunción: Centro de Documentación y Estudios, 1994.

PEREIRA, Anthony W. Ditadura e Repressão: o autoritarismo e o Estado de Direito no Brasil, no Chile e na Argentina. São Paulo: Paze Terra, 2010.

PERRONE, Fernando. Praga, São Paulo, Paris, 1968: relato de guerras. São Paulo: Busca Vida, 1988.

QUADRAT, Samantha Viz. O direito à identidade: a restituição de crianças apropriadas nos porões das ditaduras militares do Cone Sul. História, São Paulo, v. 22, n. 2, p. 167-181, 2003.

Operação Condor: o "Mercosul" do terror. Estudos Ibero-Americanos. Rio Grande do Sul. PUCRS, v.XXVIII, n.1, 2002.

RABELO, José Maria; RABELO, Thereza. Diaspora: os longos caminhos do exílio. São Paulo: Geração Editorial, 2001.

REIS, Daniel Aarão; MORAIS, Pedro. 1968: a paixão de uma utopia. Rio de Janeiro: Espaço e Tempo, 1988.

REIS, Ramiro José dos. Operação Condor e o Sequestro dos Uruguaios nas ruas de um Porto não muito Alegre. 2012. 184 f. Dissertação (Mestrado em História) - Faculdade de Filosofia e Ciências Humanas, Universidade Federal do Rio Grande do Sul, Porto Alegre, 2012.

RIBEIRO NETO, Míria; FÉRES-CARNEIRO, Terezinha. Silêncio e Luto Impossível em Famílias de Desaparecidos Políticos Brasileiros. Psicologia e Sociedade. N.24. 2012. p. 66-74.

SAIN, Marcelo Fabián. Democracia e Forças Armadas: entre a subordinação militar e os "defeitos" civil. In: D’ARAÚJO, Maria Célina; CASTRO, Celso. Democracia e Forças Armadas no Cone Sul. Rio de Janeiro: FGV, 2000.p. 22-55.

SKIDOMORE, Thomas. Brasil: de Castelo a Tancredo. Rio de Janeiro: Paz e Terra, 1988.

VASQUEZ, Ana; ARAUJO, Ana Maria, Exils latino-américains: la malédiction d'Ulysse. Paris: L'Harmattan/CEMI, 1988.

VENTURA, Zuenir. 1968: o ano que não terminou. Rio de Janeiro: Nova Fronteira, 1988.

VERA, Myrian González. "Data Feliz" no Paraguai. Festejos de 3 de novembro, aniversário de Alfredo Stroessener. In: ROLLEMBERG, Denise; QUADRAT, Samanta (Orgs.). A Construção Social dos Regimes Autoritários: legitimidade, consenso e consentimento no século XX - Brasil e América Latina. São Paulo: Civilização Brasileira, 2010.v. 1. p.393-436. 
Trabalho enviado em 21 de agosto de 2016. Aceito em 03 de março de 2017. 